\title{
In Pursuit of Healthy Aging: Effects of Nutrition on Brain Function
}

\author{
Thayza Martins Melzer ${ }^{1}$, Luana Meller Manosso ${ }^{2}$, Suk-yu Yau ${ }^{3, *}$, Joana Gil-Mohapel ${ }^{4,5}$ and \\ Patricia S. Brocardo ${ }^{1, *}$
}

check for updates

Citation: Melzer, T.M.; Manosso, L.M.; Yau, S.-y.; Gil-Mohapel, J.; Brocardo, P.S. In Pursuit of Healthy Aging: Effects of Nutrition on Brain Function. Int. J. Mol. Sci. 2021, 22, 5026. https://doi.org/10.3390/ ijms22095026

Academic Editor: Fabien Pifferi

Received: 13 April 2021

Accepted: 6 May 2021

Published: 10 May 2021

Publisher's Note: MDPI stays neutral with regard to jurisdictional claims in published maps and institutional affiliations.

Copyright: (C) 2021 by the authors Licensee MDPI, Basel, Switzerland. This article is an open access article distributed under the terms and conditions of the Creative Commons Attribution (CC BY) license (https:// creativecommons.org/licenses/by/ $4.0 /)$.
1 Neuroscience Graduate Program, Federal University of Santa Catarina, Florianópolis 88040-900, SC, Brazil; thayza.melzer@posgrad.ufsc.br

2 Translational Psychiatry Laboratory, Graduate Program in Health Sciences, University of Southern Santa Catarina, Criciúma 88806-000, SC, Brazil; luana.manosso@gmail.com

3 Department of Rehabilitation Sciences, Hong Kong Polytechnic University, Hung Hom, Hong Kong, China

4 Division of Medical Sciences, University of Victoria, Victoria, BC V8P 5C2, Canada; jgil@uvic.ca

5 Island Medical Program, Faculty of Medicine, University of British Columbia, Victoria, BC V8P 5C2, Canada

* Correspondence: sonata.yau@polyu.edu.hk (S.-y.Y.); patricia.brocardo@ufsc.br (P.S.B.)

\begin{abstract}
Consuming a balanced, nutritious diet is important for maintaining health, especially as individuals age. Several studies suggest that consuming a diet rich in antioxidants and antiinflammatory components such as those found in fruits, nuts, vegetables, and fish may reduce agerelated cognitive decline and the risk of developing various neurodegenerative diseases. Numerous studies have been published over the last decade focusing on nutrition and how this impacts health. The main objective of the current article is to review the data linking the role of diet and nutrition with aging and age-related cognitive decline. Specifically, we discuss the roles of micronutrients and macronutrients and provide an overview of how the gut microbiota-gut-brain axis and nutrition impact brain function in general and cognitive processes in particular during aging. We propose that dietary interventions designed to optimize the levels of macro and micronutrients and maximize the functioning of the microbiota-gut-brain axis can be of therapeutic value for improving cognitive functioning, particularly during aging.
\end{abstract}

Keywords: aging; cognition; macronutrients; microbiota-gut-brain axis; micronutrients; neurodegeneration; nutrition

\section{Introduction}

One of the most important factors that contribute to maintaining good health is consuming all the nutrients that the body needs to function properly [1]. According to the World Health Organization (WHO) guidelines, nutrition represents a critical part of health and development. Balanced nutrition is essential to physical and mental wellbeing throughout the entire lifespan, starting with early development during both the prenatal and postnatal stages, as well as all the way until the later stages of life [2].

The increase in average life expectancy is one of society's outstanding achievements, and this has been associated with a shift in the leading causes of morbidity and mortality, from infectious diseases to non-communicable conditions [3,4] such as diabetes, cardiovascular disease, hypertension, and stroke. The WHO guidelines highlight that the correct intake of nutrients contributes to a robust immune system, lower risk of non-communicable diseases, and ultimately, an increase in longevity [2]. Numerous epidemiological studies have shown a correlation between optimum nutrition and a decrease in cancer incidence, the reversal of chronic low-grade systemic inflammation, chronic pain, and other chronic diseases such as rheumatoid arthritis [5-8]. Specific diets can slow down symptoms of these diseases. For example, several studies indicate that the long-term consumption of a Mediterranean diet (rich in fruits, vegetables, and olive oil) correlates with better 
cognition in aged populations $[9,10]$. It seems that the same is true for neurodegenerative diseases such as Parkinson's disease (PD), Alzheimer's disease (AD), and other types of dementia [11-16]. In these cases, the available evidence has suggested that nutrition could potentially modify the onset and trajectory of these diseases through changes in biochemical and epigenetic factors $[17,18]$.

\section{Cognition and Aging}

The word "cognition" summarizes a series of processes that take place in our brain and that allow us to understand the world around us [19]. In other words, cognitive functions, such as attention, language, learning, memory, and perception, allow us to derive representations of relevant information from sensory inputs [20]. This information can be processed by the brain and used to modify behavior when necessary.

Cognitive processes are highly dependent on the prefrontal cortex, the brain area responsible for complex thinking, information analysis, and decision making [21], as well as the hippocampus and surrounding limbic structures, which are involved in learning and memory consolidation [22]. These processes are present in everyday life, at any age, in health and disease (Figure 1). In addition, for these processes to take place, the brain's structure and function need to be intact and preserved.

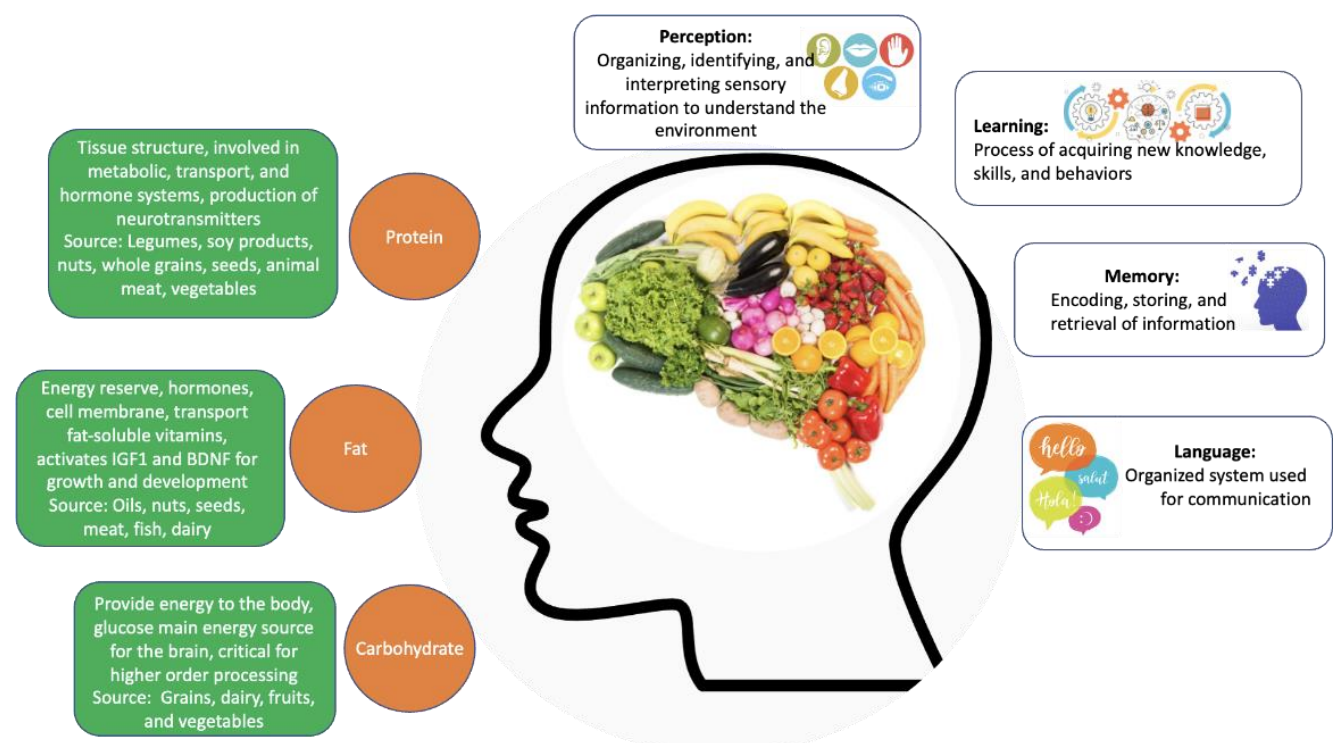

Figure 1. The contribution of individual macronutrients to brain health and cognitive function. Source: Author's own work.

Numerous intrinsic and extrinsic factors can contribute to the preservation of brain structure and function. These include, but are not limited to, intrinsic changes in neuronal plasticity and brain circuitry, exposure to different types of experiences and stimuli, physical activity, caloric, and nutritional intake, and age [23-26].

Indeed, aging in itself (i.e., independently from disease) is well known to be associated with significant changes in brain morphology, plasticity, and function $[27,28]$. In addition to this, aging in itself is one of the main risk factors for several diseases, especially neurodegenerative conditions. Moreover, age-associated changes in the brain's structure, connectivity, and intrinsic metabolic pathways are thought to contribute, at least in part, to an increased susceptibility to neurodegenerative diseases, such as various types of dementia, $\mathrm{AD}$, and $\mathrm{PD}$, which have a high prevalence among the aging population [29]. Of note, most (if not all) neurodegenerative diseases are associated with various degrees of cognitive impairment, and the decline in cognitive function is often progressive, and, in many cases, culminates in profound dementia $[30,31]$. 


\section{Nutrition}

The more straightforward way of describing a well-balanced intake of nutrients is to portray a diversified diet where the individual can consume all the necessary macronutrients and micronutrients in appropriate proportions to maintain a working body. Such diet includes a variety of fruits and vegetables, legumes (e.g., lentils and beans), nuts, and whole grains (e.g., unprocessed maize, millet, oats, wheat, and brown rice). In addition, avoiding excess fats, sugar, salt, and processed goods is also highly recommended [32]. Such diet is believed to provide numerous health benefits and reduce the risk of several chronic conditions such as diabetes, hypertension, metabolic syndrome, etc. [33,34].

Carbohydrates, proteins, and fats are the macronutrients that act as primary energy sources (Figure 1). Carbohydrates are biomolecules formed primarily by carbon, hydrogen, and oxygen atoms. They can be monosaccharides (such as glucose, the primary source of energy for all cells), disaccharides or polysaccharides, depending on the size of the carbon chain [35]. In addition to being the main energy source, carbohydrates also act as molecular beacons and participate in the formation of nucleic acids [36].

Proteins are polymers of amino acids formed by carbon, oxygen, hydrogen, nitrogen, and sulfur [37]. These macronutrients perform several crucial functions in the body, including immune defense, cell communication, catalysis of reactions, transport of substances, and forming the supporting structure of the body.

Fats or lipids are composed of glycerol and fatty acids and can be divided into various categories, including phospholipids, glycerides, and steroids [38]. These molecules are also a source of energy, in which they are kept in the body as energy reserves and, in the absence of carbohydrates, can be metabolized to generate energy. Lipids form the lipid bilayer of cell membranes, are precursors for several hormones, and facilitate the transport of fat-soluble vitamins [39].

Micronutrients, such as vitamins and minerals (Figure 2), are needed in much smaller quantities than macronutrients but are essential for numerous metabolic, biochemical, and regulatory processes [40]. Vitamins can be divided into water-soluble and fat-soluble, depending on their solubility [41-43].

Of note, a balanced nutrition is not only linked to individual health. Individuals with adequate nutrition are less likely to develop numerous chronic conditions and therefore significantly decrease the burden that such conditions impose on health care systems.

\section{Nutrition and the Aging Process}

The overall population continues to age. Data from 2019 shows that there were 703 million people over the age of 65 globally, and according to the United Nations estimates, the population over the age of 60 will reach 1.5 billion by 2050 [44]. On the other hand, the worldwide prevalence of dementia is around 50 million cases [45]. According to the World Alzheimer Report 2015, the chances an older adult has of developing some type of dementia is $2-4 \%$ at 65 years of age and increases to $15 \%$ at 80 years of age. As the population grows older, current estimates predict over 130 million cases by 2050 [46].

Given this, strategies that can promote healthy aging and offset the development of numerous chronic health conditions associated with aging are becoming increasingly relevant. Indeed, numerous studies have evaluated the potential beneficial effects of nutritional strategies in delaying the onset of age-related diseases and slowing down the progression of some conditions [47-49]. Several lines of evidence suggest that cognitive impairment and the risk of brain diseases associated with cognitive deficits including dementia can be lowered through the intake of specific macro and micronutrients present in balanced diets [50-53] and that several "special foods" can prevent or mitigate the degenerative processes associated with age, particularly B vitamins, flavonoids, and longchain $\omega-3$ fatty acids [54-56]. 


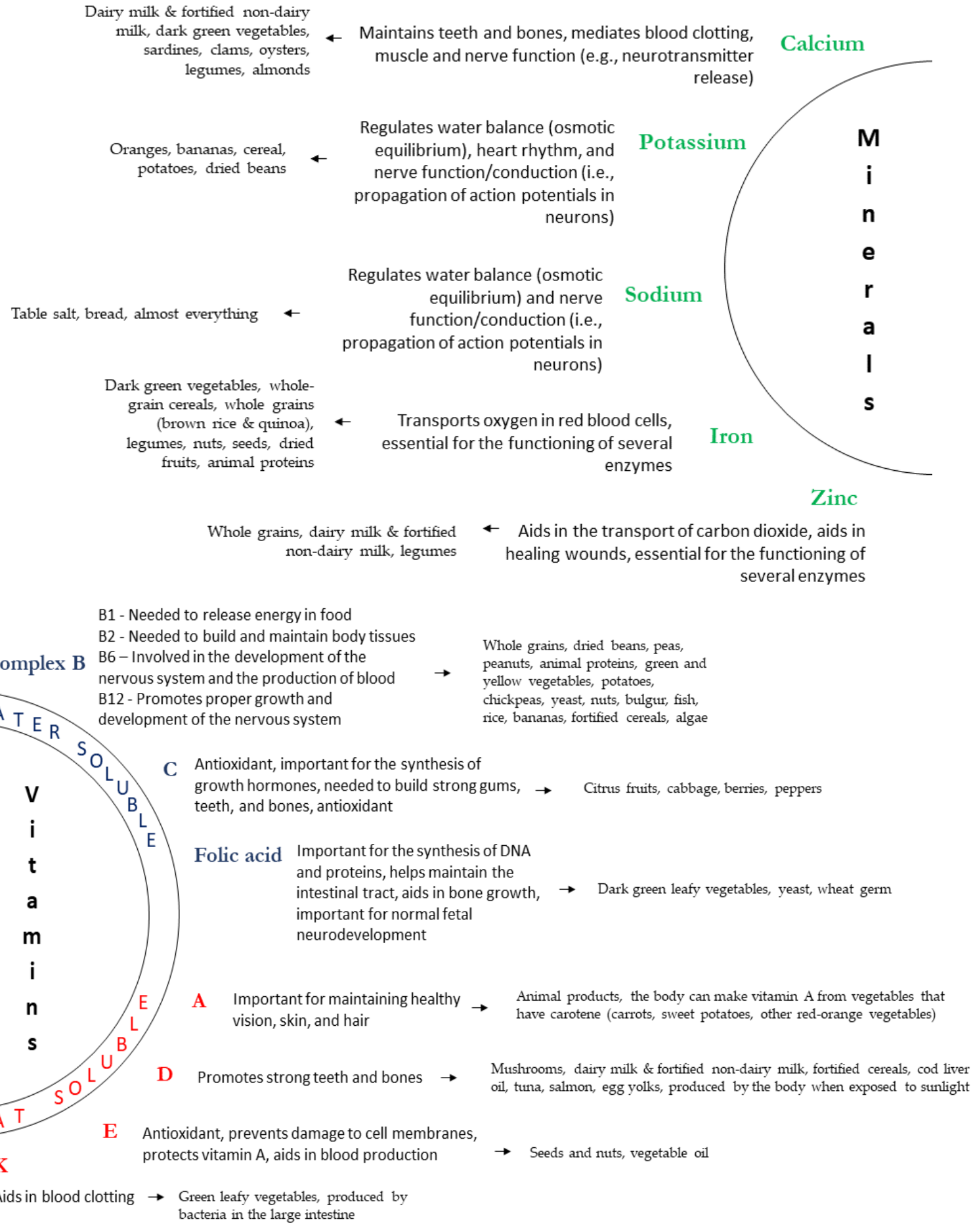

Figure 2. Main micronutrients and their sources and functions. Source: Author's own work.

Indeed, some studies have shown that nutritional supplementation improves cognitive function in patients with $\mathrm{AD}$. On a randomized, double-blind, placebo-controlled clinical trial, $210 \mathrm{AD}$ patients were randomly divided into intervention $(800 \mathrm{IU} /$ day of vitamin D) and control groups (starch granules) for 12 months. The intervention group scored better in a cognitive assessment after 6 and 12 months of supplementation [57]. Similar evidence is found in other studies. These results, however, have methodological limitations regarding study subjects, vitamin dosage, duration of intervention, and individual nutritional history [58]. Nevertheless, evidence suggests that the most appropriate approach to maximizing the health benefits of nutrients is to consume a varied, multi- 
nutrient diet rather than supplementing particular nutrients [59,60]. In support, several studies have reported a significant decrease in the risk of developing AD with increased folate [61,62] or vitamin B-6 [61] consumption. In addition, a marginal reduction in the risk of $\mathrm{AD}$ and dementia has also been reported with increased total n-3 fatty acids, DHA, and fish consumption [54,56,63-65]. However, it is still currently unclear if/how nutrition can impact and modulate cognitive function once a neurodegenerative process is initiated in the brain.

\section{Microbiota-Gut-Brain Axis and Nutrition}

The reciprocal impact of the gastrointestinal (GI) tract on brain function has been recognized since the 19th century. Presently, the microbiota-gut-brain axis is believed to form a bidirectional homeostatic communication pathway, through which the GI tract exerts an influence on brain function, and vice versa [66-69]. Indeed, all GI functions (including, motility, secretion, mucosal maintenance, and immunological defense) require regulation and coordination provided by the enteric nervous system (ENS) [70]. It is estimated that the human microbiota contains around $10^{14}$ bacterial cells, a number that is ten times greater than the number of human cells [71]. The microbiota composition is host-specific and can change according to age, sex, medication, diet, exercise, and multiple other factors $[72,73]$.

An emerging body of evidence supports the role of the microbiota-gut-brain axis on several neurological disorders, including neurodevelopmental disorders (for example, autism spectrum disorder), psychiatric disorders (for example, major depressive disorder, anxiety, and schizophrenia), and neurodegenerative disorders (for example, AD and PD) [74-78]. Indeed, clinical evidence has shown that gut microbiota changes in patients afflicted with these disorders [74,79-82].

This microbiota-gut-brain axis bidirectional communication occurs through many pathways, as outlined in the following paragraphs:

Neuroanatomic communication: The main neuroanatomical communication between the ENS (which directly innervates the GI tract) and the CNS is provided by the vagus nerve (parasympathetic input) and spinal nerves (sympathetic input). It is worth mentioning that, although the communication is bidirectional, almost $90 \%$ of vagal fibers are afferent, suggesting that the brain is primarily a receiver of information, rather than a transmitter, with regards to gut-brain communication [70]. The afferent fibers of the vagus nerve reach the nucleus tractus solitarius in the brain stem and, from there, send information to other regions of the $\mathrm{CNS}$, including regions related to cognition. The afferent fibers associated with the spinal nerves that provide innervation to the GI tract reach the CNS mainly via the spinothalamic tract, synapsing at the thalamus, and from there, information is sent to other brain regions [83,84]. Interestingly, the vagus nerve has receptors for some hormones and neurotransmitters that are produced in the GI tract, such as serotonin, cholecystokinin (CCK), YY peptide (PYY), and ghrelin, as well as receptors for bacterial fragments, such as lipopolysaccharides (LPS). Thus, the activation of these receptors can signal the brain regarding what is happening in the gut. In addition, short-chain fatty acids produced by the gut microbiota can also activate afferent fibers of the vagus nerve [84,85]. Along these lines and further supporting the microbiota-gut-brain communication, it has recently been shown that vagotomy prevents the beneficial neurobehavioral effects induced by probiotics [86]. In addition, clinical studies also suggest a beneficial role for vagus nerve stimulation in cognition [87].

Hormones and neurotransmitters: The GI tract produces more than 30 hormones and signaling molecules that influence many physiological processes and act on various tissues. At the CNS level, these hormones affect the brain centers that regulate appetite, metabolic control, and behavioral pathways linked to reward, mood, anxiety, stress, memory, etc. Some of these molecules can enter the systemic circulation, cross the blood-brain barrier (BBB), and reach the CNS. Alternatively, many can also act locally and activate afferent vagal terminals in the gut, thus generating afferent signals $[88,89]$. Through enteroendocrine cells, 
enteric neurons, and gut microbiota, the GI tract can also synthesize neurotransmitters that influence the functioning of both the GI tract and the CNS [90,91]. The neurotransmitters produced by the GI tract and gut microbiota can directly interact with the enteric and peripheral nervous systems or communicate with the brain via stimulation of vagal nerve innervation or the immune system, which in turn may influence the CNS. Of note, serotonin, catecholamines (dopamine, epinephrine, and norepinephrine), acetylcholine, and gammaaminobutyric acid (GABA) (neurotransmitters known to impact several brain functions, including cognition [92-95]) can all be synthesized in the GI tract [96,97].

Neuroendocrine pathways: Another factor that influences microbiota-gut-brain communication is stress. In the face of acute stress, the body responds by activating the hypothalamic-pituitary-adrenal (HPA) axis, which will lead to a release of cortisol by the adrenal gland. When the HPA axis is functioning normally, the neuroendocrine stress response is counter-regulated by a negative feedback mechanism. However, in some situations, such as in the case of persistent stress and/or exaggerated intensity, a deleterious effect on HPA axis regulation can be potentially detrimental to the body due to excess cortisol [98-100]. Stress can cause several GI tract changes, including changes in GI motility, GI secretions, and intestinal permeability, while also causing adverse effects on the gut microbiota [101]. Conversely, changes in microbiota can also alter the stress response. A study with germ-free animals has shown that these animals have exaggerated HPA stress response compared to animals colonized with beneficial bacteria [102]. In line with this, another preclinical study demonstrated that microbiota can modulate stress-dependent activation of pituitary and adrenal glands [103]. Noteworthy, at the CNS level, it is well recognized that chronic stress can affect the brain (and in particular hippocampal) functioning, including learning and memory processes, as well as mood regulation [99,104,105].

Immune system/inflammation: The GI tract contains about $70-80 \%$ of the body's immune cells [106]. The intestinal microbiota plays an essential role in the development and modulation of the intestinal immune system. Components of Gram-negative bacteria such as lipopolysaccharides (LPS) can interact with Toll-like receptors (TLR), influencing the immune response and the production of inflammatory cytokines, such as interleukins (IL) $[107,108]$. Peripherally produced cytokines can reach or send signals to the CNS through several mechanisms and result in neuroinflammation, which can affect the brain function and contribute to the pathophysiology of various neurological diseases [109-111]. On the other hand, the CNS regulates innate immune responses through neuronal and hormonal routes [112].

Bacteria-derived metabolites: Metabolites from bacteria, such as short-chain fatty acids (SCFAs), including acetate, propionate, and butyrate, can also influence the gut microbiotagut-brain crosstalk [89]. SCFAs are essential metabolites produced by bacterial fermentation of substrate (mostly dietary fiber) in the large intestine. Although the functions of SCFAs are not yet completely elucidated, it is believed that they may have local effects in the colon (e.g., decrease inflammation, improve mucus production), affect gene expression by inhibiting histone deacetylases, impact hormone regulation (e.g., glucagon-like peptide 1 and peptide $\mathrm{YY}$ ), and interact with vagal afferents. Moreover, SCFAs can also regulate BBB integrity/function and cross the BBB, acting directly on the brain [113,114].

Neurotrophic factors: Brain-derived neurotrophic factor (BDNF) is arguably one of the best characterized CNS neurotrophic factors. It is a key molecule involved in synaptic and structural plasticity, learning, and memory. Moreover, BDNF is associated with the pathophysiology and treatment of several neurological diseases $[115,116]$. Interestingly, intestinal microbiota can play a role in regulating BDNF levels in the CNS. Indeed, a preclinical study revealed that germ-free mice (mice that had no exposure to microorganisms) had reduced BDNF expression in the cerebral cortex and hippocampus compared to controls [102]. Another study also demonstrated that germ-free mice had lower BDNF mRNA expression in the hippocampus, cingulate cortex, and amygdala [117]. Moreover, it has been shown that peripheral administration of LPS also decreases BDNF levels in the brain [118]. On the 
other hand, animals supplemented with probiotics or prebiotics showed increased BDNF levels in various brain regions [119,120].

Numerous intrinsic and extrinsic factors have been shown to influence the microbiotagut-brain axis. These include genetic and epigenetic factors, as well as several environmental factors, such as exercise, exposure/consumption of different drugs, and consumption of probiotics (including their mode of delivery) [72]. Moreover, diet composition and nutritional status have repeatedly been shown to be one of the most critical modifiable factors regulating the gut microbiota at different time points across the lifespan and under various health conditions [121].

Within this scenario, the type of diet is a major factor that can affect the gut microbiota and the gut-brain crosstalk. The western diet (characterized by a high consumption of refined, processed foods, saturated fat, trans fat, and sugars, as well as a low intake of fruits and vegetables) has been shown to alter the gut microbiota and the functioning of the GI tract, alter the formation of SCFAs, and increase inflammation, all of which can, in turn, impact the microbiota-gut-brain axis [121,122]. In addition, most industrialized foods contain food additives and advanced glycation end products, which can also alter gut microbiota, increase inflammation, and affect the permeability of the GI tract $[123,124]$. On the other hand, a Mediterranean diet (characterized by a high consumption of fruits, vegetables, whole grains, fiber, nuts, legumes, and olive oil, as well as a low consumption of sugars, saturated fat, red and processed meats, and industrialized foods) has been shown to improve gut microbiota, reduce inflammation, and ensure the adequate production of hormones, neurotransmitters, and bacteria-derived metabolites [121,122]. In addition, a healthy diet provides a source of dietary polyphenols, a broad group of secondary plant metabolites that can modulate the microbiota-gut-brain connection by acting both at the intestine and the brain levels, since some polyphenols can cross the BBB [125].

It is important to highlight that the gut microbiota can also synthesize vitamins and influence the activation of polyphenols [126]. Some of the key nutrients that are important for gut health and, consequently, can influence the microbiota-gut-brain axis, are summarized below:

Omega-3 fatty acids: Modulate gut microbiota composition and maintain gut immunity/inflammation $[127,128]$.

Vitamin D: Modulates the immune response of the intestine as well as the gut microbiota. Induces the expression of several antimicrobial peptides in dendritic cells and contributes to maintaining adequate tight junction formation [129-131].

Vitamin A: Modulates the immune response of the intestine as well as the gut microbiota. Involved in the differentiation of mucosal epithelial cells [132-134].

Vitamin E: Protects the intestinal barrier function and modulates the gut microbiota [135].

Zinc: Modulates the immune response of the intestine, the gut microbiota, and the integrity of the mucous membranes [136,137].

Iron: Critical for the replication and survival of most bacteria [138]. However, an excess of iron can impact gut microbiota composition [139].

\section{Metabolic and Molecular Mechanisms That Contribute to Brain Aging and NeuroDegeneration}

Aging biology is intimately associated with dysregulated metabolism, which is one of the hallmarks of aging. Metabolomics use analytical profiling techniques for measuring and comparing large numbers of metabolites present in organisms [140,141]. The use of metabolomics can provide a quantitative profile of metabolites altered with age [142-144]. Metabolomics studies of aging have found that the metabolic profiles are strongly correlated with chronological age [145-148] and have pointed to some hub metabolites (nicotinamide adenine dinucleotide, reduced nicotinamide dinucleotide phosphate, $\langle$-ketoglutarate, and (B-hydroxybutyrate) that appear to play a critical role in the metabolism and signaling pathways to control aging [149]. 
Neurons are subjected to metabolic, ionic, and oxidative stress due to their electrochemical activity, bioenergetics, and various types of cellular stressors such as oxidative stress and intracellular $\mathrm{Ca}^{2+}$ dysregulation [29]. Signaling pathways evolved to respond to cellular stresses adaptively and to ease immediate threat, alert other cells, and form defenses against future stressors $[150,151]$. However, while exposure to cellular stressors increases with age, the activity and efficacy of adaptive stress responses are thought to become increasingly impaired, rendering the CNS vulnerable to injury and neurodegenerative processes [152]. This section focuses on the changes in cell metabolism that occur during the aging process, including how dysfunctional organelles and the accumulation of certain metabolites can impact the aging brain.

Mitochondria are arguably one of the most important intracellular organelles. They are responsible for energy production through the synthesis of ATP, intracellular $\mathrm{Ca}^{2+}$ homeostasis, and regulation of nuclear gene transcription [153-155]. Mitochondria are also involved in apoptosis or programmed cell death, which occurs normally in the healthy brain, but when in excess, can be linked to either acute injury or chronic neurodegenerative processes [156].

Numerous age-related mitochondrial alterations have been reported, including morphological changes [157,158], increased oxidative damage to its mitochondrial DNA [159,160], impaired functioning of the electron transport chain (ETC) [161-164], and impaired $\mathrm{Ca}^{2+}$ handling [162,165]. In addition, and as part of the natural aging process, most brain cells accumulate dysfunctional mitochondria [166,167].

Another common feature of aging is an oxidative imbalance, i.e., an increase in the production of reactive oxygen species (ROS) and/or a reduction in antioxidant defenses. The major ROS that is produced in neurons is superoxide $\left(\mathrm{O}_{2}{ }^{-}\right)$, which is generated during mitochondrial respiration [168]. Nitric oxide (NO), a reactive nitrogen species (RNS) involved in neuronal signaling, has been linked to vascular dysfunction in the aging cerebral cortex when produced in excess [169]. Peroxynitrite $\left(\mathrm{ONOO}^{-}\right.$, which results from the combination of $\mathrm{NO}$ and $\mathrm{O}_{2}{ }^{-}$) and hydroxyl radical $(\mathrm{HO})$ can initiate lipid peroxidation cascades that result in the damage of cell membranes [170]. Moreover, accumulation of 4-hydroxynonenal (HNE), a lipid peroxidation product, has been shown to be associated with the formation of amyloid deposits and neurofibrillary tangles in AD [171]. In addition, both HNE and NO can oxidize cysteine, lysine, and histidine, as well as tyrosine residues, resulting in an impaired protein function $[170,172,173]$. Finally, ROS accumulation can also cause DNA oxidation and the impairment of DNA repair mechanisms (through oxidation of protein enzymes involved in DNA repair) [174]. Indeed, both mitochondrial and nuclear DNA are regularly damaged by ROS during the normal processes of cellular metabolism. In neurons, oxidative damage to DNA is particularly increased following excitatory synaptic activity $[175,176]$. In healthy cells, oxidized DNA bases are readily removed and replaced by undamaged bases by protein enzymes involved in DNA repair pathways [177]. However, several studies have shown that aging is associated with an increase in the amount of oxidized mitochondrial and nuclear DNA and by a reduction in the activity of DNA repair mechanisms [178]. Indeed, it has been suggested that impaired DNA repair alone is sufficient to cause aging-like phenotypes, as evidenced in certain genetic diseases such as Cockayne syndrome [179].

In addition to mitochondrial changes and increased oxidative stress, intracellular $\mathrm{Ca}^{2+}$ homeostasis is also compromised in the aging brain. Studies performed on hippocampal pyramidal neurons demonstrated that aging results in an increased $\mathrm{Ca}^{2+}$ influx through $\mathrm{Ca}^{2+}$ channels, thus leading to an increase in intracellular $\mathrm{Ca}^{2+}$ concentration [180-183]. This dysregulation in intracellular $\mathrm{Ca}^{2+}$ levels can in turn impact protein phosphorylation, cytoskeletal dynamics, gene expression, mitochondrial function, and neurotransmitter release. Together, these intracellular changes can result in excitotoxicity and ultimately cell death [184].

Aging has also been associated with a decrease in the expression of several neurotrophic factors, including BDNF, nerve growth factor (NGF), and insulin growth factor 
1 (IGF-1) signaling [185-188]. In turn, these deficits can also contribute to impaired neuronal mitochondrial function, intracellular $\mathrm{Ca}^{2+}$ handling, and antioxidant defenses during aging [185].

Of note, the cell has intrinsic mechanisms to counteract the damage induced by oxidative stress and/or intracellular $\mathrm{Ca}^{2+}$ dysregulation. Oxidized proteins are tagged for proteasomal degradation through the process of ubiquitination, while oxidized/damaged membranes, mitochondria, and other intracellular organelles are targeted for degradation by lysosomes through the process of autophagy [189-191]. However, excessive ROS/RNS production and a consequent increase in levels of oxidative stress can quickly overwhelm both the proteasomal and lysosomal degradation systems, rendering them ineffective and causing cell damage and demise [192-194]. In support of this, intracellular accumulation of autophagosomes with undegraded cargos, dysfunctional mitochondria, and polyubiquitinated proteins (indicating proteasomal dysfunction) have been found in elderly individuals $[189,195,196]$ and are thought to eventually result in cell death [194]. Of note, various neuronal populations are thought to present different degrees of vulnerability to proteasome and lysosome dysfunction [197]. This differential vulnerability might contribute, at least in part, to the differences in neuronal susceptibility associated with various neurodegenerative diseases.

Other extrinsic factors are also known to contribute to neuronal degeneration in aging and/or neurodegenerative conditions. For example, it is well established that chronic exposure to uncontrolled stress (physical or psychological) can impair neuronal plasticity and predispose neurons to degeneration through hyperactivation of the hypothalamicpituitary-adrenal (HPA) axis and the resulting increase in glucocorticoid levels [198].

Glucose concentration is another important extrinsic factor that can mediate agerelated changes in the brain. Circulating glucose concentrations tend to rise during aging, as a result of impaired glucose transport in response to insulin [199,200]. In agreement, positron emission tomography (PET) imaging has shown insulin resistance and impaired glucose transport in neurons of elderly individuals, particularly in the temporal, parietal, and frontal (including motor) lobes [201]. Of note, this impairment in glucose transport seems to be more common in elderly subjects with mild cognitive impairment and AD when compared to control subjects [202]. In addition to insulin resistance, the neuronal glucose transporter (GLUT3), is vulnerable to HNE and can be easily oxidized [170,203]. On the other hand, the use of ketone bodies such as $\beta$-hydroxybutyrate (BHB) and acetoacetate do not appear to be affected by aging or neurodegeneration, as no changes in the levels of these metabolites have been observed in the brains of AD patients [204].

Together, all of the above age-induced cellular alterations culminate in neuronal dysfunction, and impaired functional (i.e., synaptic) and structural neuroplasticity (including adult hippocampal neurogenesis) [205-209]. Indeed, in the aged brain progenitor cells exhibit several features associated with mitochondrial dysregulation, including reduced mitochondrial oxidative metabolism [210], genetic alterations that affect the functioning of the mitochondrial ETC [211], and oxidative stress. In addition, impaired DNA repair, and inflammation can also contribute to the age-related reduction in adult neurogenesis seen with aging [212-215].

Finally, an increase in inflammation is also seen in the aging brain and thought to further contribute to neuronal dysfunction. In line with this, glial cells often exhibit an activated phenotype in the aged brain, leading to the release of proinflammatory cytokines, and tumor necrosis factor $\alpha$ (TNF- $\alpha)[216,217]$. In addition, there is also evidence suggesting that the complement cascade may also be activated during aging, and this process may also contribute to the pathogenesis of chronic and acute degenerative processes, such as $\mathrm{AD}$ and ischemic stroke, respectively [218-220].

\section{Prevention of Cognitive Decline through Nutritional Interventions}

This section will review some of the nutritional interventions thought to have beneficial effects with regards to cognitive function. 
A meta-analysis encompassing 15 trials and 6480 participants demonstrated that diet interventions (primarily based on the adoption of a Mediterranean diet) improved performance on measures of global cognition, executive function, and processing speed during normal aging [221]. This is also supported by a systematic review of the evidence, which indicates that adherence to a Mediterranean diet is associated with better cognitive performance. However, it should be noted that the majority of findings come from epidemiologic studies that provide evidence for a correlation between Mediterranean diet and cognition, and therefore, no cause-and-effect relationship can be asserted at this time [222].

The effects of other healthy diets on cognition and neurodegeneration have also been studied, including dietary approaches designed to prevent hypertension (DASH) [223,224], a Mediterranean-DASH diet Intervention for Neurological Delay (MIND) [224-226], and plant-based diets [227-229]. Although there are some differences among these diet patterns, it is worth noting that all of them are based on high consumption of fruits, vegetables, and whole grains and low consumption of sugars, saturated fat, and processed foods, which provide a high intake of polyphenols. The mechanisms associated with the benefits of these diets on cognition are varied, and include antioxidant and anti-inflammatory actions, modulation of gut microbiota, gut functions, and insulin sensitivity, increased neurotrophic support, and decreased neuronal damage [122,230,231].

Interestingly, these diets seem to have a long-term effect on the brain. A multicenter longitudinal study demonstrated that a Mediterranean diet and "A Priori Diet Quality Score" (APDQS) were associated with better midlife cognitive performance [232]. In addition, consumption of a wide variety of vegetables has been shown to be associated with a lower risk of global cognitive decline in older individuals [233].

A randomized clinical trial with 447 volunteers with normal cognitive function compared the effects of three distinct dietary interventions: A Mediterranean diet supplemented with extra-virgin olive oil (1 L/week), a Mediterranean diet supplemented with mixed nuts $(30 \mathrm{~g} / \mathrm{d}$ ) or a control diet (advice to reduce dietary fat). Cognitive tests performed approximately 4 years after the intervention showed that a Mediterranean diet supplemented with olive oil or mixed nuts was associated with improved cognitive function [16].

In a similar study, 31 older adults with mild cognitive impairment were randomly assigned to ingestion of Brazil nuts (one unit per day) or no nut supplementation for a period of 6 months. Twenty participants completed the trial, and improvements in verbal fluency and constructional praxis were significantly increased in the nut-supplemented group when compared with the control group. Moreover, an increase in the serum levels of selenium and in the activity of erythrocyte glutathione peroxidase were detected in the Brazil nut-supplemented group [234]. Other clinical studies also support the idea that nut consumption is associated with increased cognitive performance [235-237], and this seems to be related to their antioxidant and anti-inflammatory properties, as well as anti-amyloidogenic effects [238].

Olive oil is the primary fat source in the Mediterranean diet and the benefits of this diet on brain function have been primarily attributed to it. Olive oil contains oleic acid (a monounsaturated fatty acid) and biophenols, which have multiple pharmacological actions, including antioxidant, anti-inflammatory, and anti-amyloidogenic properties. Together, these are thought to contribute to the neuroprotective properties of olive oil $[239,240]$. In agreement, a recent clinical study revealed a significant positive correlation between cognitive function and consumption of monounsaturated fatty acids and oleic acid in elderly Japanese individuals [241].

Fish intake also seems to provide benefits with regards to brain function. A metaanalysis found a borderline significant decrease (by 36\%) in the risk to develop AD in individuals with a high intake of fish when compared with those with a low intake [242]. Another study suggested that moderate fish consumption during childhood and adolescence may be associated with some cognitive benefits. It was proposed that the consumption of fish during these developmental stages may potentially influence neuropsychological performance later on in adulthood [243]. Fish is a source of omega-3 polyunsaturated fatty 
acids, which are thought to be critical for brain functioning. Indeed, omega- 3 fatty acids are thought to contribute to cell membrane integrity and fluidity, regulation of peripheral immune function, microglial activation, and brain glucose metabolism, as well as to increase BDNF levels and decrease amyloid- $\beta$ (A $\beta$ ) load [244-248].

Cocoa flavonoids or dark chocolate ( $\geq 70 \%$ cocoa) intake also contribute to cognitive performance. Several clinical studies demonstrated that cocoa intake can improve neurovascular coupling, increase regional glucose metabolism in the occipital and visual cortex, and enhance normal cognitive functioning [249-252]. Moreover, a retrospective cohort study that included 55 patients diagnosed with amnestic mild cognitive impairment reported that cocoa flavonoids appear to decrease the progression of mild cognitive impairment to dementia [253]. In addition to neurovascular improvement, clinical and/or preclinical studies suggest that the benefits of cocoa ingestion on brain functioning may involve antioxidant and anti-inflammatory properties, increased BDNF levels, decreased levels of $A \beta$ and cortisol, as well as improvement in cholinergic neurotransmission [254-256].

Interestingly, caffeine is another compound that has been shown to have potentially beneficial effects with regards to brain function. Indeed, a clinical trial with 2513 participants aged 60 years or older suggested that caffeine was associated with increased cognitive performance [257]. A prospective cohort study in older men also suggested that coffee consumption may also be associated with reduced cognitive decline [258]. Moreover, a coffee intake of $\geq 2$ cups/day was shown to be significantly associated with lower $A \beta$ accumulation when compared with a coffee intake of $<2$ cups/day, even after controlling for potential confounders [259]. As recently reviewed, coffee and its components may exert multiple effects on the digestive tract, including antioxidant and anti-inflammatory actions, which in turn can influence the health and functioning of the gut-brain axis [260].

Another drink that seems to benefit cognition is green tea (Camellia sinensis). A systematic review (that included three cohort studies and five cross-sectional studies) supported the hypothesis that green tea intake might reduce the risk for mild cognitive impairment and cognitive impairment associated with dementia and AD. It is believed that green tea and its components (polyphenols, caffeine, and L-theanine) can exert anti-inflammatory, antioxidant, and other neuroprotective actions [261,262].

Several micronutrients appear to be important for cognition. A clinical study reported an improvement in cognition following micronutrient supplementation (A-Z multivita$\mathrm{min} /$ mineral supplement) in healthy participants [263]. On the other hand, a meta-analysis that compared plasma levels of micronutrients in $\mathrm{AD}$ patients demonstrated that these individuals had significantly lower plasma levels of folate, vitamin A, vitamin B12, vitamin C, and vitamin E when compared with healthy controls [264]. Many micronutrients play essential roles in brain functioning, being important for cellular energy production, cell maintenance, and repair, neurotransmitter synthesis, oxidation-reduction homeostasis, etc. [265]. Table 1 summarizes the clinical evidence supporting the role of micronutrients on cognition as well as their proposed mechanisms of action.

Table 1. The role of micronutrients on cognition and their potential mechanisms of action.

\begin{tabular}{|c|c|c|}
\hline Vitamin/Mineral & Clinical Evidence & Possible Mechanisms of Action \\
\hline B vitamins & $\begin{array}{c}\text { Thiamine (vitamin B1) deficiency has been associated with } \\
\text { cognitive impairment [266]. } \\
\text { Dietary intake of vitamin B6 (pyridoxine) has been associated } \\
\text { with better cognitive function [267]. } \\
\text { B12 deficiency was shown to impair memory, and serum } \\
\text { levels below } 300 \text { pmol/L were shown to cause irreversible } \\
\text { hippocampus changes [268]. } \\
\text { Folic acid (vitamin B9) supplementation was shown to } \\
\text { significantly improve cognitive function [269]. } \\
\text { Controversial data regarding the role of vitamins B6, B12, and } \\
\text { folic acid on cognition have also been reported [270]. }\end{array}$ & $\begin{array}{l}\text { B vitamins act as co-enzymes for } \\
\text { several catabolic and anabolic } \\
\text { enzymatic reactions [271]. They can } \\
\text { regulate the levels of homocysteine, } \\
\text { and S-adenosylmethionine. They have } \\
\text { anti-inflammatory [272] and } \\
\text { antioxidant [273] properties. }\end{array}$ \\
\hline
\end{tabular}




\begin{tabular}{|c|c|c|}
\hline Vitamin/Mineral & Clinical Evidence & Possible Mechanisms of Action \\
\hline Vitamin A & $\begin{array}{l}\text { Increased cognitive decline was shown to be positively } \\
\text { correlated with lower vitamin A levels and marginal vitamin } \\
\text { A deficiency was shown to facilitate AD pathogenesis [274]. } \\
\text { Vitamin A deficiency can be a predictor of mild cognitive } \\
\text { impairment [275]. } \\
\text { A higher intake of total carotenoids (which can be converted } \\
\text { to vitamin A in the body) was shown to be associated with a } \\
\text { decreased risk of moderate or poor cognitive function [276]. }\end{array}$ & $\begin{array}{l}\text { Marginal vitamin A deficiency starting } \\
\text { in the embryonic period is thought to } \\
\text { alter genes associated with AD [277]. } \\
\text { Vitamin A can be converted to retinoic } \\
\text { acid in the brain, which is essential for } \\
\text { synaptic plasticity in regions of the } \\
\text { brain involved in learning and memory, } \\
\text { such as the hippocampus [278]. }\end{array}$ \\
\hline Vitamin K & $\begin{array}{c}\text { Increased dietary vitamin } \mathrm{K} \text { intake was to shown to be } \\
\text { associated with better cognition in older adults }[279,280] \text {. } \\
\text { Oral anticoagulants that are non-vitamin K antagonists were } \\
\text { shown to be associated with a lower risk of cognitive } \\
\text { impairment when compared with vitamin K antagonists or } \\
\text { acetylsalicylic acid [281]. }\end{array}$ & $\begin{array}{l}\text { Vitamin K is involved in the } \\
\text { r-carboxylation of two vitamin } \\
\text { K-dependent proteins whose activity } \\
\text { contributes to adequate cerebral } \\
\text { homeostasis: Gas-6 and protein S. } \\
\text { Vitamin K participates as a co-factor in } \\
\text { the synthesis of sphingolipids, which } \\
\text { are essential constituents of cell } \\
\text { membranes [282]. }\end{array}$ \\
\hline Vitamin D & $\begin{array}{c}\text { Maintaining adequate vitamin D status during aging may } \\
\text { contribute to a reduction in cognitive decline and a delay in } \\
\text { the onset of dementia [283]. } \\
\text { Low vitamin D levels were shown to be associated with worse } \\
\text { cognitive performance and cognitive decline [284]. } \\
\text { Vitamin D deficiency is thought to be a risk factor for } \\
\text { AD [285]. The effects of vitamin D supplementation on } \\
\text { improving cognition are still controversial [284]. }\end{array}$ & $\begin{array}{l}\text { Vitamin D contributes to cerebral } \\
\text { activity in both the embryonic and } \\
\text { adult brain [286]. } \\
\text { Vitamin D regulates calcium } \\
\text { homeostasis, clears A } \beta \text { peptide } \\
\text { deposits, has antioxidant and } \\
\text { anti-inflammatory effects, regulates } \\
\text { brain plasticity, and improves } \\
\text { neurogenesis [287-289]. }\end{array}$ \\
\hline
\end{tabular}

A decrease in mild cognitive impairment was observed in individuals with high plasma vitamin C concentrations [290]. Blood vitamin C concentration was shown to be significantly lower in individuals with dementia when compared with healthy controls [291].

Vitamins C and E Higher vitamin E levels were shown to be associated with higher scores on verbal memory, immediate recall, and better language/verbal fluency performance, particularly among a younger age group [292].

Controversial data regarding the role of vitamin $\mathrm{E}$ on cognition have also been reported [293].

Selenium
Circulating and brain selenium concentration was shown to be significantly lower in $\mathrm{AD}$ patients when compared to healthy controls $[297,298]$.
Vitamins $\mathrm{C}$ and $\mathrm{E}$ are two important exogenous antioxidant molecules, which can decrease oxidative stress, neuroinflammation, and $\mathrm{A} \beta$ load [294-296].

Conversely to the beneficial effects associated with healthy diets, it is worth noting that some eating habits can have a deleterious impact on cognition. These include a lower vegetable intake, non-adherence to dietary guidelines, increased intake of transfat as well as processed meat, sugar, and ultra-processed foods, as well as increased alcohol consumption [300-302]. Moreover, glycemic variability has also been shown to result in oxidative stress and neuroinflammation, ultimately contributing to cognitive dysfunction [303]. Furthermore, excess levels of some minerals such as copper, manganese, iron, and zinc seem to increase the risk and/or worsen the progression of AD [304-306]. Finally, another nutritional aspect that can impact cognition is obesity. A systematic review and meta-analysis suggested a positive association between obesity in mid-life and later dementia [307]. In line with this, another meta-analysis reported that obesity increased the risk for $\mathrm{AD}$ [308] and that obese individuals have broad executive function deficits [309].

In addition, it is worth noting that combining a healthy diet with other interventions are known to have beneficial effects (e.g., physical exercise) and will likely result 
in enhanced benefits and positive outcomes. In support, findings from a double-blind, randomized controlled trial with individuals aged 60-77 years suggest that a multidomain intervention (including diet, exercise, cognitive training, and vascular risk monitoring) can improve (or at least maintain) cognitive functioning in at-risk elderly people in the general population [51].

Finally, another important nutrition-related factor that is thought to influence aging is the timing of food ingestion in relation to intrinsic circadian rhythms. Indeed, circadian rhythms optimize physiology and health by temporally coordinating cellular function, tissue function, and behavior. However, these endogenous rhythms are less efficient with age, making feeding-fasting patterns an external cue that can potentiate daily biological rhythms. It is now well recognized that both intermittent and periodic fasting as well as time-restricted feeding (TRF, in which food consumption is restricted to certain hours of the day), can be quite beneficial and help prevent and/or ameliorate several diseases. In support, sustaining a robust feeding-fasting cycle, even without altering nutrition quality or quantity, can prevent or reverse various chronic diseases in experimental models. On the other hand, dysregulated eating patterns can disrupt the temporal coordination of metabolism and physiology leading to chronic diseases that are also characteristic of aging (for review see [310,311]).

\section{Conclusions}

While it is recognized that a dietary supply of macronutrients is essential for human health, micronutrients such as vitamins and trace minerals are also crucial for maintaining brain health. In contrast, deficiency or disturbances in any of these can be associated with brain dysfunction and contribute, at least in part, to the pathophysiology of several neurological disorders. On the other hand, interventions designed to optimize the levels of such macro and micronutrients can potentially form the basis for therapeutic strategies aimed at improving cognitive functioning, particularly in the aging brain (Figure 3). Moreover, diet and nutritional status are the most critical modifiable factors regulating the gut microbiota at different time points across the lifespan and under various health conditions. Therefore, advances in our understanding of the mechanisms underlying the actions of macro and micronutrients on the brain and the microbiota-gut-brain axis will facilitate the development of nutritional interventions aimed at optimizing brain function and preventing or treating neurodegenerative disorders and other age-related conditions.

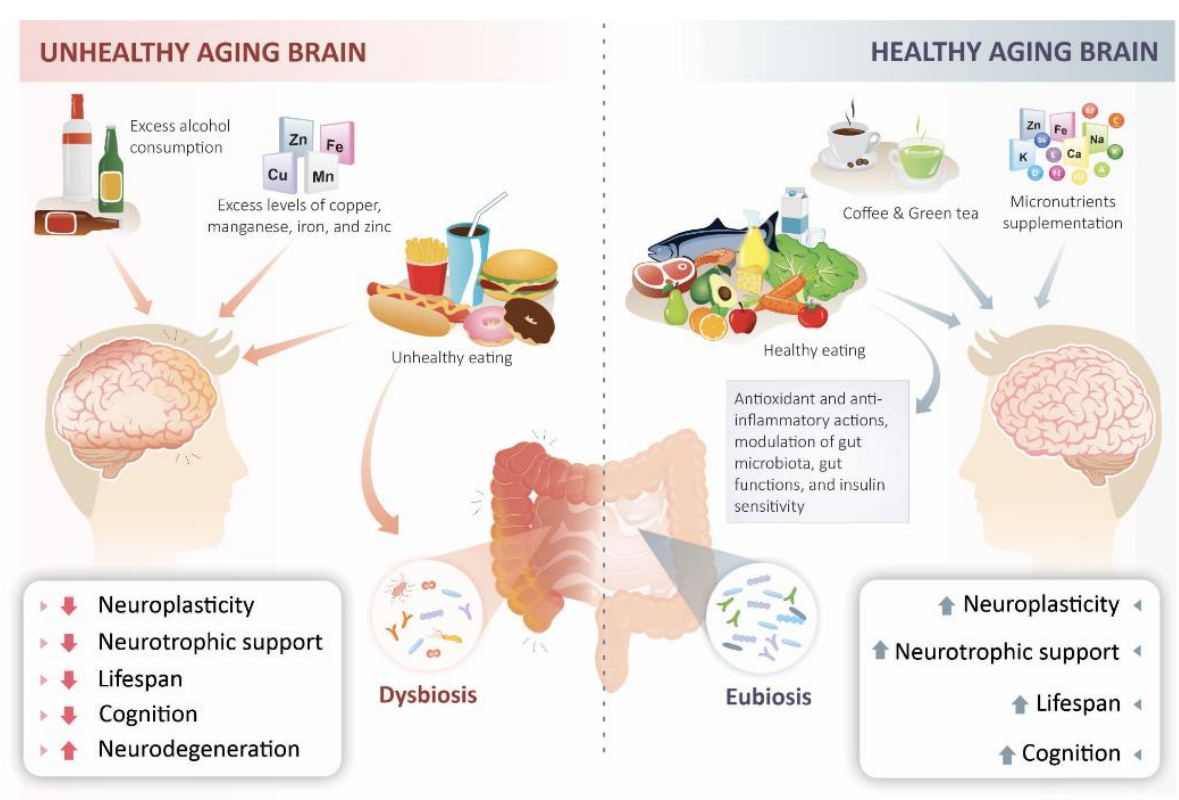

Figure 3. The contribution of diets to brain health during aging. Source: Author's own work. 
Funding: This research is funded by the open fund supported by Open Research Fund of State Key Laboratory of Brain and Cognition, University of Hong Kong; and Hong Kong Research Grant Council General Research Fund (15100018) awarded to S.Y. Yau.

Institutional Review Board Statement: Not applicable.

Informed Consent Statement: Not applicable.

Data Availability Statement: Not applicable.

Conflicts of Interest: The authors declare no conflict of interest.

\section{References}

1. Flanagan, E.; Lamport, D.; Brennan, L.; Burnet, P.; Calabrese, V.; Cunnane, S.C.; de Wilde, M.C.; Dye, L.; Farrimond, J.A.; Emerson Lombardo, N.; et al. Nutrition and the ageing brain: Moving towards clinical applications. Ageing Res. Rev. 2020, $62,101079$. [CrossRef] [PubMed]

2. FAO; IFAD; UNICEF; WFP; WHO. The State of Food Security and Nutrition in the World 2020; FAO; IFAD; UNICEF; WFP; WHO: Rome, Italy, 2020. [CrossRef]

3. Vaupel, J.W. Biodemography of human ageing. Nature 2010, 464, 536-542. [CrossRef]

4. Christensen, K.; Doblhammer, G.; Rau, R.; Vaupel, J.W. Ageing populations: The challenges ahead. Lancet 2009, $374,1196-1208$. [CrossRef]

5. Mantzorou, M.; Koutelidakis, A.; Theocharis, S.; Giaginis, C. Clinical value of nutritional status in cancer: What is its impact and how it affects disease progression and prognosis? Nutr. Cancer 2017, 69, 1151-1176. [CrossRef]

6. Custodero, C.; Mankowski, R.T.; Lee, S.A.; Chen, Z.; Wu, S.; Manini, T.M.; Hincapie Echeverri, J.; Sabbà, C.; Beavers, D.P.; Cauley, J.A.; et al. Evidence-based nutritional and pharmacological interventions targeting chronic low-grade inflammation in middle-age and older adults: A systematic review and meta-analysis. Ageing Res. Rev. 2018, 46, 42-59. [CrossRef] [PubMed]

7. Tick, H. Nutrition and pain. Phys. Med. Rehabil. Clin. N. Am. 2015, 26, 309-320. [CrossRef]

8. Philippou, E.; Nikiphorou, E. Are we really what we eat? Nutrition and its role in the onset of rheumatoid arthritis. Autoimmun. Rev. 2018, 17, 1074-1077. [CrossRef]

9. Scarmeas, N.; Stern, Y.; Mayeux, R.; Manly, J.J.; Schupf, N.; Luchsinger, J.A. Mediterranean diet and mild cognitive impairment. Arch. Neurol. 2009, 66, 216-225. [CrossRef] [PubMed]

10. Van de Rest, O.; Berendsen, A.A.M.; Haveman-Nies, A.; de Groot, L.C.P.G.M. Dietary patterns, cognitive decline, and dementia: A systematic review. Adv. Nutr. 2015, 6, 154-168. [CrossRef]

11. Gao, X.; Chen, H.; Fung, T.T.; Logroscino, G.; Schwarzschild, M.A.; Hu, F.B.; Ascherio, A. Prospective study of dietary pattern and risk of parkinson disease. Am. J. Clin. Nutr. 2007, 86, 1486-1494. [CrossRef]

12. Boulos, C.; Yaghi, N.; El Hayeck, R.; Heraoui, G.N.; Fakhoury-Sayegh, N. Nutritional risk factors, microbiota and parkinson's disease: What is the current evidence? Nutrients 2019, 11, 1896. [CrossRef]

13. Abate, G.; Marziano, M.; Rungratanawanich, W.; Memo, M.; Uberti, D. Nutrition and AGE-Ing: Focusing on alzheimer's disease. Oxid. Med. Cell. Longev. 2017, 2017. [CrossRef]

14. Hu, N.; Yu, J.-T.; Tan, L.; Wang, Y.-L.; Sun, L.; Tan, L. Nutrition and the risk of alzheimer's disease. Biomed Res. Int. 2013, 2013, 1-12. [CrossRef]

15. Jennings, A.; Cunnane, S.C.; Minihane, A.M. Can nutrition support healthy cognitive ageing and reduce dementia risk? BMJ 2020, 369, m2269. [CrossRef]

16. Valls-Pedret, C.; Sala-Vila, A.; Serra-Mir, M.; Corella, D.; De La Torre, R.; Martínez-González, M.Á.; Martínez-Lapiscina, E.H.; Fitó, M.; Pérez-Heras, A.; Salas-Salvadó, J.; et al. Mediterranean diet and age-related cognitive decline: A randomized clinical trial. JAMA Intern. Med. 2015, 175, 1094-1103. [CrossRef] [PubMed]

17. Teather, L.A. Dietary CDP-choline supplementation prevents memory impairment caused by impoverished environmental conditions in rats. Learn. Mem. 2005, 12, 39-43. [CrossRef]

18. Cummings, J.; Scheltens, P.; McKeith, I.; Blesa, R.; Harrison, J.E.; Bertolucci, P.H.F.; Rockwood, K.; Wilkinson, D.; Wijker, W.; Bennett, D.A.; et al. Effect size analyses of souvenaid in patients with alzheimer's disease. J. Alzheimer's Dis. 2016, 55, 1131-1139. [CrossRef]

19. Dresler, M.; Sandberg, A.; Bublitz, C.; Ohla, K.; Trenado, C.; Mroczko-Wasowicz, A.; Kühn, S.; Repantis, D. Hacking the brain: Dimensions of cognitive enhancement. ACS Chem. Neurosci. 2019, 10, 1137-1148. [CrossRef] [PubMed]

20. Evans, J.J. Basic concepts and principles of neuropsychological assesment. In Handbook of Clinical Neuropsychology; Gurd, J., Kischka, U., Eds.; Oxford University Press: Oxford, UK, 2010; p. 894. [CrossRef]

21. Snow, P.J. The structural and functional organization of cognition. Front. Hum. Neurosci. 2016, 10. [CrossRef] [PubMed]

22. Preston, A.R.; Eichenbaum, H. Interplay of hippocampus and prefrontal cortex in memory. Curr. Biol. 2013, 23, R764-R773. [CrossRef]

23. Singer, B.H.; Gamelli, A.E.; Fuller, C.L.; Temme, S.J.; Parent, J.M.; Murphy, G.G. Compensatory network changes in the dentate gyrus restore long-term potentiation following ablation of neurogenesis in young-adult mice. Proc. Natl. Acad. Sci. USA 2011, 108, 5437-5442. [CrossRef] [PubMed] 
24. Nomoto, K.; Schultz, W.; Watanabe, T.; Sakagami, M. Temporally extended dopamine responses to perceptually demanding reward-predictive stimuli. J. Neurosci. 2010, 30, 10692-10702. [CrossRef]

25. Fontani, G.; Corradeschi, F.; Felici, A.; Alfatti, F.; Migliorini, S.; Lodi, L. Cognitive and physiological effects of Omega-3 polyunsaturated fatty acid supplementation in healthy subjects. Eur. J. Clin. Investig. 2005, 35, 691-699. [CrossRef]

26. Han, S.; Lee, H.-S. Social capital and depression. Asia Pac. J. Public Health 2015, 27, NP2008-NP2018. [CrossRef] [PubMed]

27. Scheibel, M.E.; Lindsay, R.D.; Tomiyasu, U.; Scheibel, A.B. Progressive dendritic changes in aging human cortex. Exp. Neurol. 1975, 47, 392-403. [CrossRef]

28. Fjell, A.M.; Sneve, M.H.; Storsve, A.B.; Grydeland, H.; Yendiki, A.; Walhovd, K.B. Brain events underlying episodic memory changes in aging: A longitudinal investigation of structural and functional connectivity. Cereb. Cortex 2016, 26, 1272-1286. [CrossRef]

29. Mattson, M.P.; Arumugam, T.V. Hallmarks of brain aging: Adaptive and pathological modification by metabolic states. Cell Metab. 2018, 27, 1176-1199. [CrossRef] [PubMed]

30. Rossor, M.; Collinge, J.; Fox, N.; Mead, S.; Mummery, C.; Rohrer, J.; Schott, J.; Warren, J. Dementia and cognitive impairment. In Neurology: A Queen Square Textbook, 2nd ed.; John Wiley \& Sons, Ltd.: Hoboken, NJ, USA, 2016; Volume 30, pp. 289-336. [CrossRef]

31. Aarsland, D.; Creese, B.; Politis, M.; Chaudhuri, K.R.; Ffytche, D.H.; Weintraub, D.; Ballard, C. Cognitive decline in parkinson disease. Nat. Rev. Neurol. 2017, 13, 217-231. [CrossRef] [PubMed]

32. World Health Organization. Essential Nutrition Actions: Mainstreaming Nutrition through the Life-Course; World Health Organization (WHO): Geneva, Switzerland, 2019.

33. Seligman, H.K.; Lyles, C.; Marshall, M.B.; Prendergast, K.; Smith, M.C.; Headings, A.; Bradshaw, G.; Rosenmoss, S.; Waxman, E. A pilot food bank intervention featuring diabetes-appropriate food improved glycemic control among clients in three states. Health Aff. 2015, 34, 1956-1963. [CrossRef] [PubMed]

34. Trapl, E.S.; Smith, S.; Joshi, K.; Osborne, A.; Benko, M.; Matos, A.T.; Bolen, S. Dietary impact of produce prescriptions for patients with hypertension. Prev. Chronic Dis. 2018, 15, 180301. [CrossRef]

35. Sinnott, M.L. Structures of the open-chain forms of reducing sugar, and their carbonyl group reaction. In Carbohydrate Chemistry and Biochemistry: Structure and Mechanism; The Royal Society of Chemistry: Cambridge, UK, 2007.

36. Sears, P.; Wong, C.H. Intervention of carbohydrate recognition by proteins and nucleic acids. Proc. Natl. Acad. Sci. USA 1996, 93, 12086-12093. [CrossRef] [PubMed]

37. Schweet, R.; Heintz, R. Protein synthesis. Annu. Rev. Biochem. 1966, 35, 723-758. [CrossRef] [PubMed]

38. Hulbert, A.J.; Turner, N.; Storlien, L.H.; Else, P.L. Dietary fats and membrane function: Implications for metabolism and disease. Biol. Rev. Camb. Philos. Soc. 2005, 80, 155-169. [CrossRef]

39. Casares, D.; Escribá, P.V.; Rosselló, C.A. Membrane lipid composition: Effect on membrane and organelle structure, function and compartmentalization and therapeutic avenues. Int. J. Mol. Sci. 2019, 20, 2167. [CrossRef] [PubMed]

40. Reddy, V.S.; Palika, R.; Ismail, A.; Pullakhandam, R.; Reddy, G.B. Nutrigenomics: Opportunities \& challenges for public health nutrition. Indian J. Med. Res. 2018, 148, 632. [CrossRef]

41. Said, H.M. Intestinal absorption of water-soluble vitamins in health and disease. Biochem. J. 2011, 437, 357-372. [CrossRef] [PubMed]

42. Johnson, E.J.; Mohn, E.S. Fat-soluble vitamins. World Rev. Nutr. Diet. 2015, 111, 38-44. [CrossRef] [PubMed]

43. Elmadfa, I.; Meyer, A.L. The role of the status of selected micronutrients in shaping the immune function. Endocr. Metab. Immune Disord. Drug Targets 2019, 19, 1100-1115. [CrossRef] [PubMed]

44. United Nations. World Population Ageing 2019: Highlights; United Nations: San Francisco, CA, USA, 2019.

45. Patterson, C. World Alzheimer Report 2018; Alzheimer's Disease International: London, UK, 2018; Volume 2. [CrossRef]

46. Prince, M.; Wimo, A.; Guerchet, M.; Ali, G.C.; Wu, Y.T.; Prina, M. World Alzheimer Report 2015; Alzheimer's Disease International: London, UK, 2015.

47. Dangour, A.D.; Whitehouse, P.J.; Rafferty, K.; Mitchell, S.A.; Smith, L.; Hawkesworth, S.; Vellas, B. B-vitamins and fatty acids in the prevention and treatment of alzheimer's disease and dementia: A systematic review. J. Alzheimer's Dis. 2010, 22, 205-224. [CrossRef]

48. Moreira, S.C.; Jansen, A.K.; Silva, F.M. Dietary interventions and cognition of alzheimer's disease patients: A systematic review of randomized controlled trial. Dement. Neuropsychol. 2020, 14, 258-282. [CrossRef] [PubMed]

49. George, S.; Vlachos, N.S. Dietary interventions in mild cognitive impairment and dementia. Dialogues Clin. Neurosci. 2019, 21, 69-82. [CrossRef]

50. Scarmeas, N.; Anastasiou, C.A.; Yannakoulia, M. Nutrition and prevention of cognitive impairment. Lancet Neurol. 2018, 17, 1006-1015. [CrossRef]

51. Ngandu, T.; Lehtisalo, J.; Solomon, A.; Levälahti, E.; Ahtiluoto, S.; Antikainen, R.; Bäckman, L.; Hänninen, T.; Jula, A.; Laatikainen, T.; et al. A 2 year multidomain intervention of diet, exercise, cognitive training, and vascular risk monitoring versus control to prevent cognitive decline in at-risk elderly people (FINGER): A randomised controlled trial. Lancet 2015, 385, 2255-2263. [CrossRef] 
52. Lehtisalo, J.; Levälahti, E.; Lindström, J.; Hänninen, T.; Paajanen, T.; Peltonen, M.; Antikainen, R.; Laatikainen, T.; Strandberg, T.; Soininen, H.; et al. Dietary changes and cognition over 2 years within a multidomain intervention trial-The finnish geriatric intervention study to prevent cognitive impairment and disability (FINGER). Alzheimer's Dement. 2019, 15, 410-417. [CrossRef]

53. Samieri, C. Epidemiology and risk factors of alzheimer's disease: A focus on diet. In Biomarkers for Preclinical Alzheimer's Disease; Humana Press: New York, NY, USA, 2018; pp. 15-42. [CrossRef]

54. Morris, M.C.; Evans, D.A.; Bienias, J.L.; Tangney, C.C.; Bennett, D.A.; Wilson, R.S.; Aggarwal, N.; Schneider, J. Consumption of fish and N-3 fatty acids and risk of incident alzheimer disease. Arch. Neurol. 2003, 60, 940. [CrossRef] [PubMed]

55. Schaefer, E.J.; Bongard, V.; Beiser, A.S.; Lamon-Fava, S.; Robins, S.J.; Au, R.; Tucker, K.L.; Kyle, D.J.; Wilson, P.W.F.; Wolf, P.A. Plasma phosphatidylcholine docosahexaenoic acid content and risk of dementia and alzheimer disease. Arch. Neurol. 2006, 63, 1545. [CrossRef]

56. Barberger-Gateau, P. Fish, meat, and risk of dementia: Cohort study. BMJ 2002, 325, 932-933. [CrossRef]

57. Jia, J.; Hu, J.; Huo, X.; Miao, R.; Zhang, Y.; Ma, F. Effects of vitamin D supplementation on cognitive function and blood A $\beta$-related biomarkers in older adults with alzheimer's disease: A randomised, double-blind, placebo-controlled trial. J. Neurol. Neurosurg. Psychiatry 2019, 90, 1347-1352. [CrossRef]

58. Etgen, T.; Sander, D.; Bickel, H.; Sander, K.; Förstl, H. Vitamin D deficiency, cognitive impairment and dementia: A systematic review and meta-analysis. Dement. Geriatr. Cogn. Disord. 2012, 33, 297-305. [CrossRef]

59. Geriatric Assessment Center of Michigan. Functional Assessment of the Older Adult: Incremental Assessment; Michigan State University: Washington, DC, USA, 2003.

60. Sullivan, D.H.; Patch, G.A.; Walls, R.C.; Lipschitz, D.A. Impact of nutrition status on morbidity and mortality in a select population of geriatric rehabilitation patients. Am. J. Clin. Nutr. 1990, 51, 749-758. [CrossRef]

61. Corrada, M.M.; Kawas, C.H.; Hallfrisch, J.; Muller, D.; Brookmeyer, R. Reduced risk of alzheimer's disease with high folate intake: The baltimore longitudinal study of aging. Alzheimer's Dement. 2005, 1, 11-18. [CrossRef]

62. Luchsinger, J.A.; Tang, M.-X.; Miller, J.; Green, R.; Mayeux, R. Relation of higher folate intake to lower risk of alzheimer disease in the elderly. Arch. Neurol. 2007, 64, 86. [CrossRef] [PubMed]

63. Bo, Y.; Zhang, X.; Wang, Y.; You, J.; Cui, H.; Zhu, Y.; Pang, W.; Liu, W.; Jiang, Y.; Lu, Q. The N-3 polyunsaturated fatty acids supplementation improved the cognitive function in the chinese elderly with mild cognitive impairment: A double-blind randomized controlled trial. Nutrients 2017, 9, 54. [CrossRef]

64. Zhang, Y.-P.; Miao, R.; Li, Q.; Wu, T.; Ma, F. Effects of DHA supplementation on hippocampal volume and cognitive function in older adults with mild cognitive impairment: A 12-month randomized, double-blind, placebo-controlled trial. J. Alzheimer's Dis. 2016, 55, 497-507. [CrossRef] [PubMed]

65. Sinn, N.; Milte, C.M.; Street, S.J.; Buckley, J.D.; Coates, A.M.; Petkov, J.; Howe, P.R.C. Effects of n -3 fatty acids, EPA v . DHA, on depressive symptoms, quality of life, memory and executive function in older adults with mild cognitive impairment: A 6-month randomised controlled trial. Br. J. Nutr. 2012, 107, 1682-1693. [CrossRef] [PubMed]

66. Mayer, E.A. Gut feelings: The emerging biology of gut-brain communication. Nat. Rev. Neurosci. 2011, 12, 453-466. [CrossRef] [PubMed]

67. Allen, A.P.; Hutch, W.; Borre, Y.E.; Kennedy, P.J.; Temko, A.; Boylan, G.; Murphy, E.; Cryan, J.F.; Dinan, T.G.; Clarke, G. Bifidobacterium longum 1714 as a translational psychobiotic: Modulation of stress, electrophysiology and neurocognition in healthy volunteers. Transl. Psychiatry 2016, 6, e939. [CrossRef] [PubMed]

68. Pinto-Sanchez, M.I.; Hall, G.B.; Ghajar, K.; Nardelli, A.; Bolino, C.; Lau, J.T.; Martin, F.-P.; Cominetti, O.; Welsh, C.; Rieder, A.; et al. Probiotic bifidobacterium longum NCC3001 reduces depression scores and alters brain activity: A pilot study in patients with irritable bowel syndrome. Gastroenterology 2017, 153, 448-459.e8. [CrossRef]

69. Fond, G.; Loundou, A.; Hamdani, N.; Boukouaci, W.; Dargel, A.; Oliveira, J.; Roger, M.; Tamouza, R.; Leboyer, M.; Boyer, L. Anxiety and depression comorbidities in irritable bowel syndrome (IBS): A systematic review and meta-analysis. Eur. Arch. Psychiatry Clin. Neurosci. 2014, 264, 651-660. [CrossRef] [PubMed]

70. Rao, M.; Gershon, M.D. The bowel and beyond: The enteric nervous system in neurological disorders. Nat. Rev. Gastroenterol. Hepatol. 2016, 13, 517-528. [CrossRef]

71. Savage, D.C. Microbial ecology of the gastrointestinal tract. Annu. Rev. Microbiol. 1977, 31, 107-133. [CrossRef] [PubMed]

72. Cryan, J.F.; O'riordan, K.J.; Cowan, C.S.M.; Sandhu, K.V.; Bastiaanssen, T.F.S.; Boehme, M.; Codagnone, M.G.; Cussotto, S.; Fulling, C.; Golubeva, A.V.; et al. The microbiota-gut-brain axis. Physiol. Rev. 2019, 99, 1877-2013. [CrossRef]

73. Stilling, R.M.; Dinan, T.G.; Cryan, J.F. Microbial genes, brain \& behaviour-Epigenetic regulation of the gut-brain axis. Genes Brain Behav. 2014, 13, 69-86. [CrossRef] [PubMed]

74. Sanada, K.; Nakajima, S.; Kurokawa, S.; Barceló-Soler, A.; Ikuse, D.; Hirata, A.; Yoshizawa, A.; Tomizawa, Y.; Salas-Valero, M.; Noda, Y.; et al. Gut microbiota and majore depressive disorder: A systematic review and meta-analysis. J. Affect. Disord. 2020, 266, 1-13. [CrossRef]

75. Srikantha, P.; Mohajeri, H.M. The possible role of the microbiota-gut-brain-axis in autism spectrum disorder. Int. J. Mol. Sci. 2019, 20, 2115. [CrossRef]

76. Foster, J.A.; McVey Neufeld, K.A. Gut-brain axis: How the microbiome influences anxiety and depression. Trends Neurosci. 2013, 36, 305-312. [CrossRef] [PubMed] 
77. Westfall, S.; Lomis, N.; Kahouli, I.; Dia, S.Y.; Singh, S.P.; Prakash, S. Microbiome, probiotics and neurodegenerative diseases: Deciphering the gut brain axis. Cell. Mol. Life Sci. 2017, 74, 3769-3787. [CrossRef]

78. Nemani, K.; Hosseini Ghomi, R.; McCormick, B.; Fan, X. Schizophrenia and the gut-brain axis. Prog. Neuro Psychopharmacol. Biol. Psychiatry 2015, 56, 155-160. [CrossRef]

79. Iglesias-vázquez, L.; Riba, G.V.G.; Arija, V.; Canals, J. Composition of gut microbiota in children with autism spectrum disorder: A systematic review and meta-analysis. Nutrients 2020, 12, 792. [CrossRef] [PubMed]

80. Xu, R.; Wu, B.; Liang, J.; He, F.; Gu, W.; Li, K.; Luo, Y.; Chen, J.; Gao, Y.; Wu, Z.; et al. Altered gut microbiota and mucosal immunity in patients with schizophrenia. Brain. Behav. Immun. 2020, 85, 120-127. [CrossRef]

81. Zhuang, Z.Q.; Shen, L.L.; Li, W.W.; Fu, X.; Zeng, F.; Gui, L.; Lü, Y.; Cai, M.; Zhu, C.; Tan, Y.L.; et al. Gut microbiota is altered in patients with alzheimer's disease. J. Alzheimer's Dis. 2018, 63, 1337-1346. [CrossRef]

82. Petrov, V.A.; Saltykova, I.V.; Zhukova, I.A.; Alifirova, V.M.; Zhukova, N.G.; Dorofeeva, Y.B.; Tyakht, A.V.; Kovarsky, B.A.; Alekseev, D.G.; Kostryukova, E.S.; et al. Analysis of gut microbiota in patients with parkinson's disease. Bull. Exp. Biol. Med. 2017, 162, 734-737. [CrossRef] [PubMed]

83. Wang, H.X.; Wang, Y.P. Gut microbiota-brain axis. Chin. Med. J. 2016, 129, 2373-2380. [CrossRef] [PubMed]

84. Breit, S.; Kupferberg, A.; Rogler, G.; Hasler, G. Vagus nerve as modulator of the brain-gut axis in psychiatric and inflammatory disorders. Front. Psychiatry 2018, 9, 44. [CrossRef]

85. Bonaz, B.; Bazin, T.; Pellissier, S. The vagus nerve at the interface of the microbiota-gut-brain axis. Front. Neurosci. 2018, $12,49$. [CrossRef] [PubMed]

86. Bravo, J.A.; Forsythe, P.; Chew, M.V.; Escaravage, E.; Savignac, H.M.; Dinan, T.G.; Bienenstock, J.; Cryan, J.F. Ingestion of lactobacillus strain regulates emotional behavior and central GABA receptor expression in a mouse via the vagus nerve. Proc. Natl. Acad. Sci. USA 2011, 108, 16050-16055. [CrossRef] [PubMed]

87. Vonck, K.; Raedt, R.; Naulaerts, J.; De Vogelaere, F.; Thiery, E.; Van Roost, D.; Aldenkamp, B.; Miatton, M.; Boon, P. Vagus nerve stimulation ... 25 years later! What do we know about the effects on cognition? Neurosci. Biobehav. Rev. 2014, 45, 63-71. [CrossRef]

88. Skibicka, K.P.; Dickson, S.L. Enteroendocrine hormones-Central effects on behavior. Curr. Opin. Pharmacol. 2013, 13, 977-982. [CrossRef] [PubMed]

89. Martin, C.R.; Osadchiy, V.; Kalani, A.; Mayer, E.A. The brain-gut-microbiome axis. CMGH 2018, 6, 133-148. [CrossRef] [PubMed]

90. Morais, L.H.; Schreiber, H.L.; Mazmanian, S.K. The gut microbiota-brain axis in behaviour and brain disorders. Nat. Rev. Microbiol. 2020, 1-15. [CrossRef] [PubMed]

91. Mittal, R.; Debs, L.H.; Patel, A.P.; Nguyen, D.; Patel, K.; O'Connor, G.; Grati, M.; Mittal, J.; Yan, D.; Eshraghi, A.A.; et al. Neurotransmitters: The critical modulators regulating gut-brain axis. J. Cell. Physiol. 2017, 232, 2359-2372. [CrossRef]

92. Jenkins, T.A.; Nguyen, J.C.D.; Polglaze, K.E.; Bertrand, P.P. Influence of tryptophan and serotonin on mood and cognition with a possible role of the gut-brain axis. Nutrients 2016, 8, 56. [CrossRef] [PubMed]

93. Hasselmo, M.E. The role of acetylcholine in learning and memory. Curr. Opin. Neurobiol. 2006, 16, 710-715. [CrossRef]

94. Michels, L.; Martin, E.; Klaver, P.; Edden, R.; Zelaya, F.; Lythgoe, D.J.; Lüchinger, R.; Brandeis, D.; O'Gorman, R.L. Frontal GABA levels change during working memory. PLOS ONE 2012, 7, e31933. [CrossRef]

95. James, T.; Kula, B.; Choi, S.; Khan, S.S.; Bekar, L.K.; Smith, N.A. Locus coeruleus in memory formation and alzheimer's disease. Eur. J. Neurosci. 2020,1-12. [CrossRef]

96. Strandwitz, P. Neurotransmitter modulation by the gut microbiota. Brain Res. 2018, 1693, 128-133. [CrossRef] [PubMed]

97. Gao, W.; Baumgartel, K.L.; Alexander, S.A. The gut microbiome as a component of the gut-brain axis in cognitive health. Biol. Res. Nurs. 2020, 22, 485-494. [CrossRef]

98. Kyrou, I.; Tsigos, C. Stress hormones: Physiological stress and regulation of metabolism. Curr. Opin. Pharmacol. 2009, 9, 787-793. [CrossRef] [PubMed]

99. Lupien, S.J.; Juster, R.P.; Raymond, C.; Marin, M.F. The effects of chronic stress on the human brain: From neurotoxicity, to vulnerability, to opportunity. Front. Neuroendocrinol. 2018, 49, 91-105. [CrossRef]

100. Smith, S.M.; Vale, W.W. The role of the hypothalamic-pituitary-adrenal axis in neuroendocrine responses to stress. Dialogues Clin. Neurosci. 2006, 8, 383-395. [CrossRef] [PubMed]

101. Konturek, P.C.; Brzozowski, T.; Konturek, S.J. Stress and the gut: Pathophysiology, clinical consequences, diagnostic approach and treatment options. J. Physiol. Pharmacol. 2011, 62, 591-599.

102. Sudo, N.; Chida, Y.; Aiba, Y.; Sonoda, J.; Oyama, N.; Yu, X.N.; Kubo, C.; Koga, Y. Postnatal microbial colonization programs the hypothalamic-pituitary-adrenal system for stress response in mice. J. Physiol. 2004, 558, 263-275. [CrossRef] [PubMed]

103. Vodička, M.; Ergang, P.; Hrnčíř, T.; Mikulecká, A.; Kvapilová, P.; Vagnerová, K.; Šestáková, B.; Fajstová, A.; Hermanová, P.; Hudcovic, T.; et al. Microbiota affects the expression of genes involved in HPA axis regulation and local metabolism of glucocorticoids in chronic psychosocial stress. Brain. Behav. Immun. 2018, 73, 615-624. [CrossRef] [PubMed]

104. Schwabe, L.; Joëls, M.; Roozendaal, B.; Wolf, O.T.; Oitzl, M.S. Stress effects on memory: An update and integration. Neurosci. Biobehav. Rev. 2012, 36, 1740-1749. [CrossRef]

105. Wingenfeld, K.; Wolf, O.T. HPA axis alterations in mental disorders: Impact on memory and its relevance for therapeutic interventions. CNS Neurosci. Ther. 2011, 17, 714-722. [CrossRef] [PubMed] 
106. Yoo, B.B.; Mazmanian, S.K. The enteric network: Interactions between the immune and nervous systems of the gut. Immunity 2017, 46, 910-926. [CrossRef]

107. Belkaid, Y.; Hand, T.W. Role of the microbiota in immunity and inflammation. Cell 2014, 157, 121-141. [CrossRef] [PubMed]

108. Powell, N.; Walker, M.M.; Talley, N.J. The mucosal immune system: Master regulator of bidirectional gut-brain communications. Nat. Rev. Gastroenterol. Hepatol. 2017, 14, 143-159. [CrossRef]

109. Kaufmann, F.N.; Costa, A.P.; Ghisleni, G.; Diaz, A.P.; Rodrigues, A.L.S.; Peluffo, H.; Kaster, M.P. NLRP3 inflammasome-driven pathways in depression: Clinical and preclinical findings. Brain. Behav. Immun. 2017, 64, 367-383. [CrossRef] [PubMed]

110. Becher, B.; Spath, S.; Goverman, J. Cytokine networks in neuroinflammation. Nat. Rev. Immunol. 2017, 17, 49-59. [CrossRef]

111. Heneka, M.T.; Carson, M.J.; El Khoury, J.; Landreth, G.E.; Brosseron, F.; Feinstein, D.L.; Jacobs, A.H.; Wyss-Coray, T.; Vitorica, J.; Ransohoff, R.M.; et al. Neuroinflammation in alzheimer's disease. Lancet Neurol. 2015, 14, 388-405. [CrossRef]

112. Sternberg, E.M. Neural regulation of innate immunity: A coordinated nonspecific host response to pathogens. Nat. Rev. Immunol. 2006, 6, 318-328. [CrossRef] [PubMed]

113. Dalile, B.; Van Oudenhove, L.; Vervliet, B.; Verbeke, K. The role of short-chain fatty acids in microbiota-gut-brain communication. Nat. Rev. Gastroenterol. Hepatol. 2019, 16, 461-478. [CrossRef] [PubMed]

114. Silva, Y.P.; Bernardi, A.; Frozza, R.L. The role of short-chain fatty acids from gut microbiota in gut-brain communication. Front. Endocrinol. 2020, 11. [CrossRef]

115. Kowiański, P.; Lietzau, G.; Czuba, E.; Waśkow, M.; Steliga, A.; Moryś, J. BDNF: A key factor with multipotent impact on brain signaling and synaptic plasticity. Cell. Mol. Neurobiol. 2018, 38, 579-593. [CrossRef]

116. Cunha, C.; Brambilla, R.; Thomas, K.L. A simple role for BDNF in learning and memory? Front. Mol. Neurosci. 2010, 3, 1-14. [CrossRef] [PubMed]

117. Heijtz, R.D.; Wang, S.; Anuar, F.; Qian, Y.; Bjorkholm, B.; Samuelsson, A.; Hibberd, M.L.; Forssberg, H.; Pettersson, S. Normal gut microbiota modulates brain development and behavior. Proc. Natl. Acad. Sci. USA 2011, 108, 3047-3052. [CrossRef]

118. Wang, J.; Jia, Y.; Li, G.; Wang, B.; Zhou, T.; Zhu, L.; Chen, T.; Chen, Y. The dopamine receptor D3 regulates lipopolysaccharideinduced depressive-like behavior in mice. Int. J. Neuropsychopharmacol. 2018, 21, 448-460. [CrossRef]

119. Savignac, H.M.; Corona, G.; Mills, H.; Chen, L.; Spencer, J.P.E.; Tzortzis, G.; Burnet, P.W.J. Prebiotic feeding elevates central brain derived neurotrophic factor, N-Methyl-d-Aspartate receptor subunits and d-Serine. Neurochem. Int. 2013, 63, 756-764. [CrossRef]

120. Ait-Belgnaoui, A.; Colom, A.; Braniste, V.; Ramalho, L.; Marrot, A.; Cartier, C.; Houdeau, E.; Theodorou, V.; Tompkins, T. Probiotic gut effect prevents the chronic psychological stress-induced brain activity abnormality in mice. Neurogastroenterol. Motil. 2014, 26, 510-520. [CrossRef]

121. Sandhu, K.V.; Sherwin, E.; Schellekens, H.; Stanton, C.; Dinan, T.G.; Cryan, J.F. Feeding the microbiota-gut-brain axis: Diet, microbiome, and neuropsychiatry. Transl. Res. 2017, 179, 223-244. [CrossRef]

122. Agustí, A.; García-Pardo, M.P.; López-Almela, I.; Campillo, I.; Maes, M.; Romaní-Pérez, M.; Sanz, Y. Interplay between the gut-brain axis, obesity and cognitive function. Front. Neurosci. 2018, 12, 155. [CrossRef]

123. Rapin, J.R.; Wiernsperger, N. Possible links between intestinal permeablity and food processing: A potential therapeutic niche for glutamine. Clinics 2010, 65, 635-643. [CrossRef] [PubMed]

124. Holder, M.K.; Chassaing, B. Impact of food additives on the gut-brain axis. Physiol. Behav. 2018, 192, 173-176. [CrossRef] [PubMed]

125. Serra, D.; Almeida, L.M.; Dinis, T.C.P. Dietary polyphenols: A novel strategy to modulate microbiota-gut-brain axis. Trends Food Sci. Technol. 2018, 78, 224-233. [CrossRef]

126. Rowland, I.; Gibson, G.; Heinken, A.; Scott, K.; Swann, J.; Thiele, I.; Tuohy, K. Gut microbiota functions: Metabolism of nutrients and other food components. Eur. J. Nutr. 2018, 57, 1-24. [CrossRef]

127. Costantini, L.; Molinari, R.; Farinon, B.; Merendino, N. Impact of Omega-3 fatty acids on the gut microbiota. Int. J. Mol. Sci. 2017, 18, 2645. [CrossRef]

128. Pusceddu, M.M.; El Aidy, S.; Crispie, F.; O'Sullivan, O.; Cotter, P.; Stanton, C.; Kelly, P.; Cryan, J.F.; Dinan, T.G. N-3 polyunsaturated fatty acids (PUFAs) reverse the impact of early-life stress on the gut microbiota. PLoS ONE 2015, 10, e0139721. [CrossRef]

129. Tabatabaeizadeh, S.-A.; Tafazoli, N.; Ferns, G.; Avan, A.; Ghayour-Mobarhan, M. Vitamin D, the gut microbiome and inflammatory bowel disease. J. Res. Med. Sci. 2018, 23, 75. [CrossRef] [PubMed]

130. Yamamoto, E.A.; Jørgensen, T.N. Relationships between Vitamin D, gut microbiome, and systemic autoimmunity. Front. Immunol. 2020, 10, 3141. [CrossRef]

131. Ooi, J.H.; Chen, J.; Cantorna, M.T. Vitamin D regulation of immune function in the gut: Why do T cells have vitamin D receptors? Mol. Aspects Med. 2012, 33, 77-82. [CrossRef] [PubMed]

132. Iwata, M.; Hirakiyama, A.; Eshima, Y.; Kagechika, H.; Kato, C.; Song, S.-Y. Retinoic acid imprints gut-homing specificity on T cells. Immunity 2004, 21, 527-538. [CrossRef]

133. Biesalski, H.K.; Nohr, D. New aspects in vitamin a metabolism: The role of retinyl esters as systemic and local sources for retinol in mucous epithelia. J. Nutr. 2004, 134 (Suppl. 12), 3453S-3457S. [CrossRef] [PubMed]

134. Brown, C.C.; Noelle, R.J. Seeing through the dark: New insights into the immune regulatory functions of vitamin A. Eur. J. Immunol. 2015, 45, 1287-1295. [CrossRef] [PubMed]

135. Liu, K.Y.; Nakatsu, C.H.; Jones-Hall, Y.; Kozik, A.; Jiang, Q. Vitamin E alpha- and gamma-tocopherol mitigate colitis, protect intestinal barrier function and modulate the gut microbiota in mice. Free Radic. Biol. Med. 2021, 163, 180-189. [CrossRef] 
136. Zackular, J.P.; Moore, J.L.; Jordan, A.T.; Juttukonda, L.J.; Noto, M.J.; Nicholson, M.R.; Crews, J.D.; Semler, M.W.; Zhang, Y.; Ware, L.B.; et al. Dietary zinc alters the microbiota and decreases resistance to clostridium difficile infection. Nat. Med. 2016, 22, 1330-1334. [CrossRef] [PubMed]

137. Vela, G.; Stark, P.; Socha, M.; Sauer, A.K.; Hagmeyer, S.; Grabrucker, A.M. Zinc in gut-brain interaction in autism and neurological disorders. Neural Plast. 2015, 2015, 1-15. [CrossRef]

138. Yilmaz, B.; Li, H. Gut microbiota and iron: The crucial actors in health and disease. Pharmaceuticals 2018, 11, 98. [CrossRef]

139. Rusu, I.G.; Suharoschi, R.; Vodnar, D.C.; Pop, C.R.; Socaci, S.A.; Vulturar, R.; Istrati, M.; Moroșan, I.; Fărcaș, A.C.; Kerezsi, A.D.; et al. Iron supplementation influence on the gut microbiota and probiotic intake effect in iron deficiency-A literature-based review. Nutrients 2020, 12, 1993. [CrossRef]

140. Valdes, A.M.; Glass, D.; Spector, T.D. Omics technologies and the study of human ageing. Nat. Rev. Genet. 2013, 14, 601-607. [CrossRef]

141. Ivanisevic, J.; Siuzdak, G. The role of metabolomics in brain metabolism research. J. Neuroimmune Pharmacol. 2015, 10, 391-395. [CrossRef]

142. Zierer, J.; Menni, C.; Kastenmüller, G.; Spector, T.D. Integration of 'Omics' data in aging research: From biomarkers to systems biology. Aging Cell 2015, 14, 933-944. [CrossRef] [PubMed]

143. Cevenini, E.; Bellavista, E.; Tieri, P.; Castellani, G.; Lescai, F.; Francesconi, M.; Mishto, M.; Santoro, A.; Valensin, S.; Salvioli, S.; et al. Systems biology and longevity: An emerging approach to identify innovative anti- aging targets and strategies. Curr. Pharm. Des. 2010, 16, 802-813. [CrossRef] [PubMed]

144. Jové, M.; Portero-Otín, M.; Naudí, A.; Ferrer, I.; Pamplona, R. Metabolomics of human brain aging and age-related neurodegenerative diseases. J. Neuropathol. Exp. Neurol. 2014, 73, 640-657. [CrossRef]

145. Cheng, S.; Larson, M.G.; McCabe, E.L.; Murabito, J.M.; Rhee, E.P.; Ho, J.E.; Jacques, P.F.; Ghorbani, A.; Magnusson, M.; Souza, A.L.; et al. Distinct metabolomic signatures are associated with longevity in humans. Nat. Commun. 2015, 6, 6791. [CrossRef] [PubMed]

146. Ivanisevic, J.; Stauch, K.L.; Petrascheck, M.; Benton, H.P.; Epstein, A.A.; Fang, M.; Gorantla, S.; Tran, M.; Hoang, L.; Kurczy, M.E.; et al. Metabolic drift in the aging brain. Aging 2016, 8, 1000-1020. [CrossRef]

147. Menni, C.; Kastenmüller, G.; Petersen, A.K.; Bell, J.T.; Psatha, M.; Tsai, P.-C.; Gieger, C.; Schulz, H.; Erte, I.; John, S.; et al. Metabolomic markers reveal novel pathways of ageing and early development in human populations. Int. J. Epidemiol. 2013, 42, 1111-1119. [CrossRef] [PubMed]

148. Vaarhorst, A.A.M.; Beekman, M.; Suchiman, E.H.D.; van Heemst, D.; Houwing-Duistermaat, J.J.; Westendorp, R.G.J.; Slagboom, P.E.; Heijmans, B.T. Lipid metabolism in long-lived families: The leiden longevity study. Age 2011, 33, 219-227. [CrossRef]

149. Sharma, R.; Ramanathan, A. The aging metabolome-Biomarkers to hub metabolites. Proteomics 2020, 20, 1800407. [CrossRef]

150. Scandalios, J.G. Oxidative stress: Molecular perception and transduction of signals. Braz. J. Med. Biol. Res. 2005, 38, 995-1014. [CrossRef]

151. Muralidharan, S.; Mandrekar, P. Cellular stress response and innate immune signaling: Integrating pathways in host defense and inflammation. J. Leukoc. Biol. 2013, 94, 1167-1184. [CrossRef]

152. Stranahan, A.M.; Mattson, M.P. Recruiting adaptive cellular stress responses for successful brain ageing. Nat. Rev. Neurosci. 2012, 13, 209-216. [CrossRef]

153. Hou, Y.; Ouyang, X.; Wan, R.; Cheng, H.; Mattson, M.P.; Cheng, A. Mitochondrial superoxide production negatively regulates neural progenitor proliferation and cerebral cortical development. Stem. Cells 2012, 30, 2535-2547. [CrossRef]

154. Yun, J.; Finkel, T. Mitohormesis. Cell Metab. 2014, 19, 757-766. [CrossRef]

155. Raefsky, S.M.; Mattson, M.P. Adaptive responses of neuronal mitochondria to bioenergetic challenges: Roles in neuroplasticity and disease resistance. Free Radic. Biol. Med. 2017, 102, 203-216. [CrossRef] [PubMed]

156. Mattson, M.P. Apoptosis in neurodegenerative disorders. Nat. Rev. Mol. Cell Biol. 2000, 1, 120-129. [CrossRef]

157. Stahon, K.E.; Bastian, C.; Griffith, S.; Kidd, G.J.; Brunet, S.; Baltan, S. Age-related changes in axonal and mitochondrial ultrastructure and function in white matter. J. Neurosci. 2016, 36, 9990-10001. [CrossRef] [PubMed]

158. Morozov, Y.M.; Datta, D.; Paspalas, C.D.; Arnsten, A.F.T. Ultrastructural evidence for impaired mitochondrial fission in the aged rhesus monkey dorsolateral prefrontal cortex. Neurobiol. Aging 2017, 51, 9-18. [CrossRef]

159. Kim, G.W.; Chan, P.H. Oxidative stress and neuronal DNA fragmentation mediate age-dependent vulnerability to the mitochondrial toxin, 3-nitropropionic acid, in the mouse striatum. Neurobiol. Dis. 2001, 8, 114-126. [CrossRef] [PubMed]

160. Santos, R.X.; Correia, S.C.; Zhu, X.; Smith, M.A.; Moreira, P.I.; Castellani, R.J.; Nunomura, A.; Perry, G. Mitochondrial DNA oxidative damage and repair in aging and alzheimer's disease. Antioxid. Redox Signal. 2013, 18, 2444-2457. [CrossRef]

161. Yao, J.; Hamilton, R.T.; Cadenas, E.; Brinton, R.D. Decline in mitochondrial bioenergetics and shift to ketogenic profile in brain during reproductive senescence. Biochim. Biophys. Acta Gen. Subj. 2010, 1800, 1121-1126. [CrossRef] [PubMed]

162. Pandya, J.D.; Grondin, R.; Yonutas, H.M.; Haghnazar, H.; Gash, D.M.; Zhang, Z.; Sullivan, P.G. Decreased mitochondrial bioenergetics and calcium buffering capacity in the basal ganglia correlates with motor deficits in anonhuman primate model of aging. Neurobiol. Aging 2015, 36, 1903-1913. [CrossRef] [PubMed]

163. Pandya, J.D.; Royland, J.E.; MacPhail, R.C.; Sullivan, P.G.; Kodavanti, P.R.S. Age- and brain region-specific differences in mitochondrial bioenergetics in brown norway rats. Neurobiol. Aging 2016, 42, 25-34. [CrossRef]

164. Pollard, A.K.; Craig, E.L.; Chakrabarti, L. Mitochondrial complex 1 activity measured by spectrophotometry is reduced across all brain regions in ageing and more specifically in neurodegeneration. PLoS ONE 2016, 11, e0157405. [CrossRef] [PubMed] 
165. Leslie, S.W.; Chandler, L.J.; Barr, E.M.; Farrar, R.P. Reduced calcium uptake by rat brain mitochondria and synaptosomes in response to aging. Brain Res. 1985, 329, 177-183. [CrossRef]

166. Lin, D.T.; Wu, J.; Holstein, D.; Upadhyay, G.; Rourk, W.; Muller, E.; Lechleiter, J.D. Ca2+ signaling, mitochondria and sensitivity to oxidative stress in aging astrocytes. Neurobiol. Aging 2007, 28, 99-111. [CrossRef]

167. Ghosh, D.; LeVault, K.R.; Barnett, A.J.; Brewer, G.J. A reversible early oxidized redox state that precedes macromolecular ROS damage in aging nontransgenic and 3xTg-AD mouse neurons. J. Neurosci. 2012, 32, 5821-5832. [CrossRef]

168. Halliwell, B. Role of free radicals in the neurodegenerative diseases. Drugs Aging 2001, 18, 685-716. [CrossRef]

169. Park, L.; Anrather, J.; Girouard, H.; Zhou, P.; Iadecola, C. Nox2-derived reactive oxygen species mediate neurovascular dysregulation in the aging mouse brain. J. Cereb. Blood Flow Metab. 2007, 27, 1908-1918. [CrossRef]

170. Mattson, M.P. Roles of the lipid peroxidation product 4-hydroxynonenal in obesity, the metabolic syndrome, and associated vascular and neurodegenerative disorders. Exp. Gerontol. 2009, 44, 625-633. [CrossRef] [PubMed]

171. Papaioannod, N.; Tooten, P.C.J.; Van Ederen, A.M.; Jiirgen, R.E.; Rofina, J.; Tsangaris, T.; Gruys, E. Immunohistochemical investigation of the brain of aged dogs. I. Detection of neurofibrillary tangles and of 4-hydroxynonenal protein, an oxidative damage product, in senile plaques. J. Protein Fold. Disord. 2001, 21, 11-21. [CrossRef]

172. Guix, F.X.; Uribesalgo, I.; Coma, M.; Muñoz, F.J. The physiology and pathophysiology of nitric oxide in the brain. Prog. Neurobiol. 2005, 76, 126-152. [CrossRef]

173. Perluigi, M.; Swomley, A.M.; Butterfield, D.A. Redox proteomics and the dynamic molecular landscape of the aging brain. Ageing Res. Rev. 2014, 13, 75-89. [CrossRef] [PubMed]

174. Cooke, M.S.; Evans, M.D.; Dizdaroglu, M.; Lunec, J. Oxidative DNA damage: Mechanisms, mutation, and disease. FASEB J. 2003, 17, 1195-1214. [CrossRef] [PubMed]

175. Chow, H.M.; Herrup, K. Genomic integrity and the ageing brain. Nat. Rev. Neurosci. 2015, 16, 672-684. [CrossRef]

176. Yang, J.L.; Tadokoro, T.; Keijzers, G.; Mattson, M.P.; Bohr, V.A. Neurons efficiently repair glutamate-induced oxidative DNA damage by a process involving creb-mediated up-regulation of apurinic endonuclease 1. J. Biol. Chem. 2010, 285, 28191-28199. [CrossRef]

177. Leandro, G.S.; Sykora, P.; Bohr, V.A. The impact of base excision DNA repair in age-related neurodegenerative diseases. Mutat. Res. Mol. Mech. Mutagen. 2015, 776, 31-39. [CrossRef]

178. Lu, T.; Pan, Y.; Kao, S.Y.; Li, C.; Kohane, I.; Chan, J.; Yankner, B.A. Gene regulation and DNA damage in the ageing human brain. Nature 2004, 429, 883-891. [CrossRef]

179. Scheibye-Knudsen, M. Neurodegeneration in accelerated aging. Dan. Med. J. 2016, 63, 1-21.

180. Thibault, O.; Hadley, R.; Landfield, P.W. Elevated Postsynaptic [CA2+]i and L-Type calcium channel activity in aged hippocampal neurons: Relationship to impaired synaptic plasticity. J. Neurosci. 2001, 21, 9744-9756. [CrossRef]

181. Toescu, E.C.; Verkhratsky, A.; Landfield, P.W. Ca 2+ regulation and gene expression in normal brain aging. Trends Neurosci. 2004, 27, 614-620. [CrossRef] [PubMed]

182. Gant, J.C.; Sama, M.M.; Landfield, P.W.; Thibault, O. Early and simultaneous emergence of multiple hippocampal biomarkers of aging is mediated by Ca2+-Induced Ca2+ release. J. Neurosci. 2006, 26, 3482-3490. [CrossRef]

183. Porte, Y.; Buhot, M.C.; Mons, N. Alteration of CREB phosphorylation and spatial memory deficits in aged 129T2/Sv Mice. Neurobiol. Aging 2008, 29, 1533-1546. [CrossRef] [PubMed]

184. Camandola, S.; Mattson, M.P. Aberrant subcellular neuronal calcium regulation in aging and alzheimer's disease. Biochim. Biophys. Acta Mol. Cell Res. 2011, 1813, 965-973. [CrossRef] [PubMed]

185. Mattson, M.P.; Maudsley, S.; Martin, B. A Neural signaling triumvirate that influences ageing and age-related disease: Insulin/IGF1, BDNF and serotonin. Ageing Res. Rev. 2004, 3, 445-464. [CrossRef] [PubMed]

186. Tapia-Arancibia, L.; Aliaga, E.; Silhol, M.; Arancibia, S. New insights into brain bdnf function in normal aging and alzheimer disease. Brain Res. Rev. 2008, 59, 201-220. [CrossRef]

187. Schliebs, R.; Arendt, T. The cholinergic system in aging and neuronal degeneration. Behav. Brain Res. 2011, $221,555-563$. [CrossRef] [PubMed]

188. Neidl, R.; Schneider, A.; Bousiges, O.; Majchrzak, M.; Barbelivien, A.; de Vasconcelos, A.P.; Dorgans, K.; Doussau, F.; Loeffler, J.P.; Cassel, J.C.; et al. Late-life environmental enrichment induces acetylation events and nuclear factor kb-dependent regulations in the hippocampus of aged rats showing improved plasticity and learning. J. Neurosci. 2016, 36, 4351-4361. [CrossRef]

189. Nixon, R.A. The role of autophagy in neurodegenerative disease. Nat. Med. 2013, 19, 983-997. [CrossRef] [PubMed]

190. Galluzzi, L.; Baehrecke, E.H.; Ballabio, A.; Boya, P.; Bravo-San Pedro, J.M.; Cecconi, F.; Choi, A.M.; Chu, C.T.; Codogno, P.; Colombo, M.I.; et al. Molecular definitions of autophagy and related processes. EMBO J. 2017, 36, 1811-1836. [CrossRef]

191. VerPlank, J.J.S.; Goldberg, A.L. Regulating protein breakdown through proteasome phosphorylation. Biochem. J. 2017, 474, 3355-3371. [CrossRef] [PubMed]

192. Keller, J.N.; Gee, J.; Ding, Q. The proteasome in brain aging. Ageing Res. Rev. 2002, 1, 279-293. [CrossRef]

193. Butler, D.; Bahr, B.A. Oxidative stress and lysosomes: CNS-related consequences and implications for lysosomal enhancement strategies and induction of autophagy. Antioxid. Redox Signal. 2006, 8, 185-196. [CrossRef] [PubMed]

194. Zhang, S.; Eitan, E.; Mattson, M.P. Early involvement of lysosome dysfunction in the degeneration of cerebral cortical neurons caused by the lipid peroxidation product 4-Hydroxynonenal. J. Neurochem. 2017, 140, 941-954. [CrossRef] 
195. Graham, S.H.; Liu, H. Life and death in the trash heap: The ubiquitin proteasome pathway and UCHL1 in brain aging, neurodegenerative disease and cerebral ischemia. Ageing Res. Rev. 2017, 34, 30-38. [CrossRef]

196. Kerr, J.S.; Adriaanse, B.A.; Greig, N.H.; Mattson, M.P.; Cader, M.Z.; Bohr, V.A.; Fang, E.F. Mitophagy and alzheimer's disease: Cellular and molecular mechanisms. Trends Neurosci. 2017, 40, 151-166. [CrossRef] [PubMed]

197. Keller, J.N.; Hanni, K.B.; Markesbery, W.R. Possible Involvement of Proteasome Inhibition in Aging: Implications for Oxidative Stress. Mech. Ageing Dev. 2000, 113, 61-70. [CrossRef]

198. McEwen, B.S.; Morrison, J.H. The brain on stress: Vulnerability and plasticity of the prefrontal cortex over the life course. Neuron 2013, 79, 16-29. [CrossRef]

199. Thambisetty, M.; Beason-Held, L.L.; An, Y.; Kraut, M.; Metter, J.; Egan, J.; Ferrucci, L.; O’Brien, R.; Resnick, S.M. Impaired glucose tolerance in midlife and longitudinal changes in brain function during aging. Neurobiol. Aging 2013, 34, 2271-2276. [CrossRef]

200. Neth, B.J.; Craft, S. Insulin resistance and alzheimer's disease: Bioenergetic linkages. Front. Aging Neurosci. 2017, 9, 1-20. [CrossRef]

201. Goyal, M.S.; Vlassenko, A.G.; Blazey, T.M.; Su, Y.; Couture, L.E.; Durbin, T.J.; Bateman, R.J.; Benzinger, T.L.-S.; Morris, J.C.; Raichle, M.E. Loss of brain aerobic glycolysis in normal human aging. Cell Metab. 2017, 26, 353-360.e3. [CrossRef]

202. Kato, T.; Inui, Y.; Nakamura, A.; Ito, K. Brain fluorodeoxyglucose (FDG) PET in dementia. Ageing Res. Rev. 2016, 30, 73-84. [CrossRef]

203. Mark, R.J.; Pang, Z.; Geddes, J.W.; Uchida, K.; Mattson, M.P. Amyloid $\beta$-peptide impairs glucose transport in hippocampal and cortical neurons: Involvement of membrane lipid peroxidation. J. Neurosci. 1997, 17, 1046-1054. [CrossRef] [PubMed]

204. Cunnane, S.C.; Courchesne-Loyer, A.; Vandenberghe, C.; St-Pierre, V.; Fortier, M.; Hennebelle, M.; Croteau, E.; Bocti, C.; Fulop, T.; Castellano, C.A. Can ketones help rescue brain fuel supply in later life? Implications for cognitive health during aging and the treatment of alzheimer's disease. Front. Mol. Neurosci. 2016, 9, 1-21. [CrossRef] [PubMed]

205. Erdö, F.; Denes, L.; De Lange, E. Age-associated physiological and pathological changes at the blood-brain barrier: A review. J. Cereb. Blood Flow Metab. 2017, 37, 4-24. [CrossRef]

206. Oberman, L.; Pascual-Leone, A. Changes in plasticity across the lifespan: Cause of disease and target for intervention. Prog. Brain Res. 2013, 207, 91-120. [CrossRef] [PubMed]

207. Cuestas Torres, D.M.; Cardenas, F.P. Synaptic plasticity in alzheimer's disease and healthy aging. Rev. Neurosci. 2020, 31, 245-268. [CrossRef] [PubMed]

208. Lazarov, O.; Mattson, M.P.; Peterson, D.A.; Pimplikar, S.W.; van Praag, H. When neurogenesis encounters aging and disease. Trends Neurosci. 2010, 33, 569-579. [CrossRef]

209. Gil-Mohapel, J.; Brocardo, P.S.; Choquette, W.; Gothard, R.; Simpson, J.M.; Christie, B.R. Hippocampal neurogenesis levels predict WATERMAZE search strategies in the aging brain. PLoS ONE 2013, 8, e75125. [CrossRef] [PubMed]

210. Stoll, E.A.; Cheung, W.; Mikheev, A.M.; Sweet, I.R.; Bielas, J.H.; Zhang, J.; Rostomily, R.C.; Horner, P.J. Aging neural progenitor cells have decreased mitochondrial content and lower oxidative metabolism. J. Biol. Chem. 2011, 286, 38592-38601. [CrossRef] [PubMed]

211. Beckervordersandforth, R.; Ebert, B.; Schäffner, I.; Moss, J.; Fiebig, C.; Shin, J.; Moore, D.L.; Ghosh, L.; Trinchero, M.F.; Stockburger, C.; et al. Role of mitochondrial metabolism in the control of early lineage progression and aging phenotypes in adult hippocampal neurogenesis. Neuron 2017, 93, 560-573.e6. [CrossRef] [PubMed]

212. Ekdahl, C.T.; Claasen, J.H.; Bonde, S.; Kokaia, Z.; Lindvall, O. Inflammation is detrimental for neurogenesis in adult brain. Proc. Natl. Acad. Sci. USA 2003, 100, 13632-13637. [CrossRef]

213. So, J.K.; Tae, G.S.; Hee, R.P.; Park, M.; Kim, M.S.; Hyung, S.K.; Hae, Y.C.; Mattson, M.P.; Lee, J. Curcumin stimulates proliferation of embryonic neural progenitor cells and neurogenesis in the adult hippocampus. J. Biol. Chem. 2008, 283, 14497-14505. [CrossRef]

214. Regnell, C.E.; Hildrestrand, G.A.; Sejersted, Y.; Medin, T.; Moldestad, O.; Rolseth, V.; Krokeide, S.Z.; Suganthan, R.; Luna, L.; Bjørås, M.; et al. Hippocampal adult neurogenesis is maintained by Neil3-dependent repair of oxidative DNA lesions in neural progenitor cells. Cell Rep. 2012, 2, 503-510. [CrossRef] [PubMed]

215. L'Episcopo, F.; Tirolo, C.; Testa, N.; Caniglia, S.; Morale, M.C.; Impagnatiello, F.; Pluchino, S.; Marchetti, B. Aging-Induced Nrf2ARE pathway disruption in the subventricular zone drives neurogenic impairment in parkinsonian mice via PI3K-Wnt/ $\beta$-catenin dysregulation. J. Neurosci. 2013, 33, 1462-1485. [CrossRef]

216. Cribbs, D.H.; Berchtold, N.C.; Perreau, V.; Coleman, P.D.; Rogers, J.; Tenner, A.J.; Cotman, C.W. Extensive innate immune gene activation accompanies brain aging, increasing vulnerability to cognitive decline and neurodegeneration: A microarray study. $J$. Neuroinflamm. 2012, 9, 1-18. [CrossRef] [PubMed]

217. Norden, D.M.; Godbout, J.P. Review: Microglia of the aged brain: Primed to be activated and resistant to regulation. Neuropathol. Appl. Neurobiol. 2013, 39, 19-34. [CrossRef] [PubMed]

218. Arumugam, T.V.; Woodruff, T.M.; Lathia, J.D.; Selvaraj, P.K.; Mattson, M.P.; Taylor, S.M. Neuroprotection in stroke by complement inhibition and immunoglobulin therapy. Neuroscience 2009, 158, 1074-1089. [CrossRef] [PubMed]

219. Stephan, A.H.; Madison, D.V.; Mateos, J.M.; Fraser, D.A.; Lovelett, E.A.; Coutellier, L.; Kim, L.; Tsai, H.H.; Huang, E.J.; Rowitch, D.H.; et al. A dramatic increase of C1q protein in the CNS during normal aging. J. Neurosci. 2013, 33, 13460-13474. [CrossRef]

220. Hong, S.; Beja-glasser, V.F.; Nfonoyim, B.M.; Frouin, A.; Ramakrishnan, S.; Merry, K.M.; Shi, Q.; Rosenthal, A.; Barres, A.; Lemere, C.A.; et al. ADF/Cofilin-Actin rods in neurodegenerative diseases. Curr. Alzheimer Res. 2016, 352, 712-716. [CrossRef] 
221. McEvoy, C.T.; Leng, Y.; Peeters, G.M.; Kaup, A.R.; Allen, I.E.; Yaffe, K. Interventions involving a major dietary component improve cognitive function in cognitively healthy adults: A systematic review and meta-analysis. Nutr. Res. 2019, 66, 1-12. [CrossRef]

222. Petersson, S.D.; Philippou, E. Mediterranean diet, cognitive function, and dementia: A systematic review of the evidence. Adv. Nutr. 2016, 7, 889-904. [CrossRef] [PubMed]

223. Tangney, C.C.; Li, H.; Wang, Y.; Barnes, L.; Schneider, J.A.; Bennett, D.A.; Morris, M.C. Relation of DASH- and mediterranean-like dietary patterns to cognitive decline in older persons. Neurology 2014, 83, 1410-1416. [CrossRef]

224. Van Den Brink, A.C.; Brouwer-Brolsma, E.M.; Berendsen, A.A.M.; Van De Rest, O. The mediterranean, dietary approaches to stop hypertension (DASH), and mediterranean-DASH intervention for neurodegenerative delay (MIND) diets are associated with less cognitive decline and a lower risk of alzheimer's disease-A review. Adv. Nutr. 2019, 10, 1040-1065. [CrossRef] [PubMed]

225. Morris, M.C.; Tangney, C.C.; Wang, Y.; Sacks, F.M.; Barnes, L.L.; Bennett, D.A.; Aggarwal, N.T. MIND diet slows cognitive decline with aging. Alzheimer's Dement. 2015, 11, 1015-1022. [CrossRef]

226. Hosking, D.E.; Eramudugolla, R.; Cherbuin, N.; Anstey, K.J. MIND not mediterranean diet related to 12-year incidence of cognitive impairment in an australian longitudinal cohort study. Alzheimer's Dement. 2019, 15, 581-589. [CrossRef]

227. Medawar, E.; Huhn, S.; Villringer, A.; Veronica Witte, A. The effects of plant-based diets on the body and the brain: A systematic review. Transl. Psychiatry 2019, 9, 226. [CrossRef] [PubMed]

228. Rajaram, S.; Jones, J.; Lee, G.J. Plant-based dietary patterns, plant foods, and age-related cognitive decline. Adv. Nutr. 2019, 10, 422-436. [CrossRef]

229. Ramey, M.M.; Shields, G.S.; Yonelinas, A.P. Markers of a plant-based diet relate to memory and executive function in older adults. Nutr. Neurosci. 2020, 1-10. [CrossRef] [PubMed]

230. McGrattan, A.M.; McGuinness, B.; McKinley, M.C.; Kee, F.; Passmore, P.; Woodside, J.V.; McEvoy, C.T. Diet and inflammation in cognitive ageing and alzheimer's disease. Curr. Nutr. Rep. 2019, 8, 53-65. [CrossRef] [PubMed]

231. El-Swefy, S.E.; Atteia, H.H. Molecular aspects of the mediterranean diet: Adiponectin, brain amyloid precursor protein, apolipoprotein e and caspase-3 MRNA. In The Mediterranean Diet: An Evidence-Based Approach; Elsevier Inc.: Amsterdam, The Netherlands, 2015; pp. 441-448. [CrossRef]

232. Mcevoy, C.T.; Hoang, T.; Sidney, S.; Steffen, L.M.; Jacobs, D.R.; Shikany, J.M.; Wilkins, J.T.; Yaffe, K. Dietary patterns during adulthood and cognitive performance in midlife: The CARDIA study. Neurology 2019, 92, E1589-E1599. [CrossRef] [PubMed]

233. Chou, Y.C.; Lee, M.S.; Chiou, J.M.; Chen, T.F.; Chen, Y.C.; Chen, J.H. Association of diet quality and vegetable variety with the risk of cognitive decline in chinese older adults. Nutrients 2019, 11, 1666. [CrossRef]

234. Rita Cardoso, B.; Apolinário, D.; da Silva Bandeira, V.; Busse, A.L.; Magaldi, R.M.; Jacob-Filho, W.; Cozzolino, S.M.F. Effects of brazil nut consumption on selenium status and cognitive performance in older adults with mild cognitive impairment: A randomized controlled pilot trial. Eur. J. Nutr. 2016, 55, 107-116. [CrossRef]

235. O'Brien, J.; Okereke, O.; Devore, E.; Rosner, B.; Breteler, M.; Grodstein, F. Long-term intake of nuts in relation to cognitive function in older women. J. Nutr. Health Aging 2014, 18, 496-502. [CrossRef]

236. Arab, L.; Ang, A. A cross sectional study of the association between walnut consumption and cognitive function among adult us populations represented in NHANES. J. Nutr. Health Aging 2015, 19, 284-290. [CrossRef]

237. Pribis, P.; Bailey, R.N.; Russell, A.A.; Kilsby, M.A.; Hernandez, M.; Craig, W.J.; Grajales, T.; Shavlik, D.J.; Sabatè, J. Effects of walnut consumption on cognitive performance in young adults. Br. J. Nutr. 2012, 107, 1393-1401. [CrossRef] [PubMed]

238. Chauhan, A.; Chauhan, V. Beneficial effects of walnuts on cognition and brain health. Nutrients 2020, 12, 550. [CrossRef]

239. Angeloni, C.; Malaguti, M.; Barbalace, M.C.; Hrelia, S. Bioactivity of olive oil phenols in neuroprotection. Int. J. Mol. Sci. 2017, 18, 2230. [CrossRef]

240. Omar, S.H. Mediterranean and MIND diets containing olive biophenols reduces the prevalence of alzheimer's disease. Int. J. Mol. Sci. 2019, 20, 2797. [CrossRef]

241. Sakurai, K.; Shen, C.; Shiraishi, I.; Inamura, N.; Hisatsune, T. Consumption of oleic acid on the preservation of cognitive functions in Japanese elderly individuals. Nutrients 2021, 13, 284. [CrossRef] [PubMed]

242. Wu, S.; Ding, Y.; Wu, F.; Li, R.; Hou, J.; Mao, P. Omega-3 fatty acids intake and risks of dementia and alzheimer's disease: A meta-analysis. Neurosci. Biobehav. Rev. 2015, 48, 1-9. [CrossRef]

243. Butler, L.J.; Janulewicz, P.A.; Carwile, J.L.; White, R.F.; Winter, M.R.; Aschengrau, A. Childhood and adolescent fish consumption and adult neuropsychological performance: An analysis from the cape cod health study. Neurotoxicol. Teratol. 2017, 61, 47-57. [CrossRef] [PubMed]

244. Layé, S.; Nadjar, A.; Joffre, C.; Bazinet, R.P. Anti-inflammatory effects of Omega-3 fatty acids in the brain: Physiological mechanisms and relevance to pharmacology. Pharmacol. Rev. 2018, 70, 12-38. [CrossRef] [PubMed]

245. Wysoczański, T.; Sokoła-Wysoczańska, E.; Pękala, J.; Lochyński, S.; Czyż, K.; Bodkowski, R.; Herbinger, G.; Patkowska-Sokoła, B.; Librowski, T. Omega-3 fatty acids and their role in central nervous system-A review. Curr. Med. Chem. 2016, $23,816-831$. [CrossRef] [PubMed]

246. Pifferi, F.; Cunnane, S.C.; Guesnet, P. Evidence of the role of Omega-3 polyunsaturated fatty acids in brain glucose metabolism. Nutrients 2020, 12, 1382. [CrossRef] [PubMed]

247. Deacon, G.; Kettle, C.; Hayes, D.; Dennis, C.; Tucci, J. Omega 3 polyunsaturated fatty acids and the treatment of depression. Crit. Rev. Food Sci. Nutr. 2017, 57, 212-223. [CrossRef] 
248. Belkouch, M.; Hachem, M.; Elgot, A.; Van, A.L.; Picq, M.; Guichardant, M.; Lagarde, M.; Bernoud-Hubac, N. The pleiotropic effects of Omega-3 docosahexaenoic acid on the hallmarks of alzheimer's disease. J. Nutr. Biochem. 2016, 38, 1-11. [CrossRef]

249. Decroix, L.; De Pauw, K.; Van Cutsem, J.; Pattyn, N.; Heyman, E.; Meeusen, R. Acute Cocoa Flavanols intake improves cerebral hemodynamics while maintaining brain activity and cognitive performance in moderate hypoxia. Psychopharmacology 2018, 235, 2597-2608. [CrossRef] [PubMed]

250. Lamport, D.J.; Christodoulou, E.; Achilleos, C. Beneficial effects of dark chocolate for episodic memory in healthy young adults: A parallel-groups acute intervention with a white chocolate control. Nutrients 2020, 12, 483. [CrossRef]

251. Fox, M.; Meyer-Gerspach, A.C.; Wendebourg, M.J.; Gruber, M.; Heinrich, H.; Sauter, M.; Woelnerhanssen, B.; Koeberle, D.; Juengling, F. Effect of cocoa on the brain and gut in healthy subjects: A randomised controlled trial. Br. J. Nutr. 2019, 121, 654-661. [CrossRef] [PubMed]

252. Socci, V.; Tempesta, D.; Desideri, G.; De Gennaro, L.; Ferrara, M. Enhancing human cognition with cocoa flavonoids. Front. Nutr. 2017, 4, 16. [CrossRef]

253. Calabrò, R.S.; De Cola, M.C.; Gervasi, G.; Portaro, S.; Naro, A.; Accorinti, M.; Manuli, A.; Marra, A.; De Luca, R.; Bramanti, P. The efficacy of cocoa polyphenols in the treatment of mild cognitive impairment: A retrospective study. Medicina 2019, 55, 156. [CrossRef]

254. Cova, I.; Leta, V.; Mariani, C.; Pantoni, L.; Pomati, S. Exploring cocoa properties: Is theobromine a cognitive modulator? Psychopharmacology 2019, 236, 561-572. [CrossRef] [PubMed]

255. Tsang, C.; Hodgson, L.; Bussu, A.; Farhat, G.; Al-Dujaili, E. Effect of polyphenol-rich dark chocolate on salivary cortisol and mood in adults. Antioxidants 2019, 8, 149. [CrossRef] [PubMed]

256. Madhavadas, S.; Kapgal, V.K.; Kutty, B.M.; Subramanian, S. The neuroprotective effect of dark chocolate in monosodium glutamate-induced nontransgenic alzheimer disease model rats: Biochemical, behavioral, and histological studies. J. Diet. Suppl. 2016, 13, 449-460. [CrossRef] [PubMed]

257. Dong, X.; Li, S.; Sun, J.; Li, Y.; Zhang, D. Association of coffee, decaffeinated coffee and caffeine intake from coffee with cognitive performance in older adults: National health and nutrition examination survey (NHANES) 2011-2014. Nutrients 2020, 12, 840. [CrossRef]

258. Van Gelder, B.M.; Buijsse, B.; Tijhuis, M.; Kalmijn, S.; Giampaoli, S.; Nissinen, A.; Kromhout, D. Coffee consumption is inversely associated with cognitive decline in elderly european men: The FINE study. Eur. J. Clin. Nutr. 2007, 61, 226-232. [CrossRef]

259. Kim, J.W.; Byun, M.S.; Yi, D.; Lee, J.H.; Jeon, S.Y.; Jung, G.; Lee, H.N.; Sohn, B.K.; Lee, J.Y.; Kim, Y.K.; et al. Coffee intake and decreased amyloid pathology in human brain. Transl. Psychiatry 2019, 9, 270. [CrossRef]

260. Iriondo-Dehond, A.; Uranga, J.A.; Del Castillo, M.D.; Abalo, R. Effects of coffee and its components on the gastrointestinal tract and the brain-gut axis. Nutrients 2021, 13,88. [CrossRef]

261. Prasanth, M.I.; Sivamaruthi, B.S.; Chaiyasut, C.; Tencomnao, T. A Review of the role of green tea (Camellia Sinensis) in antiphotoaging, stress resistance, neuroprotection, and autophagy. Nutrients 2019, 11, 474. [CrossRef]

262. Chen, S.Q.; Wang, Z.S.; Ma, Y.X.; Zhang, W.; Lu, J.L.; Liang, Y.R.; Zheng, X.Q. Neuroprotective effects and mechanisms of tea bioactive components in neurodegenerative diseases. Molecules 2018, 23, 512. [CrossRef] [PubMed]

263. Denniss, R.J.; Barker, L.A.; Day, C.J. Improvement in cognition following double-blind randomized micronutrient interventions in the general population. Front. Behav. Neurosci. 2019, 13, 115. [CrossRef] [PubMed]

264. Lopes Da Silva, S.; Vellas, B.; Elemans, S.; Luchsinger, J.; Kamphuis, P.; Yaffe, K.; Sijben, J.; Groenendijk, M.; Stijnen, T. Plasma nutrient status of patients with alzheimer's disease: Systematic review and meta-analysis. Alzheimer's Dement. 2014, 10, 485-502. [CrossRef] [PubMed]

265. Bourre, J.M. Effects of nutrients (in Food) on the structure and function of the nervous system: Update on dietary requirements for brain. Part 1: Micronutrients. J. Nutr. Health Aging 2006, 10, 377-385.

266. Gibson, G.E.; Hirsch, J.A.; Fonzetti, P.; Jordan, B.D.; Cirio, R.T.; Elder, J. Vitamin B1 (Thiamine) and dementia. Ann. N. Y. Acad. Sci. 2016, 1367, 21-30. [CrossRef] [PubMed]

267. Fortune, N.C.; Harville, E.W.; Guralnik, J.M.; Gustat, J.; Chen, W.; Qi, L.; Bazzano, L.A. Dietary intake and cognitive function: Evidence from the bogalusa heart study. Am. J. Clin. Nutr. 2019, 109, 1656-1663. [CrossRef] [PubMed]

268. Smith, A.D. Hippocampus as a mediator of the role of vitamin B-12 in memory. Am. J. Clin. Nutr. 2016, 103, 959-960. [CrossRef]

269. Durga, J.; van Boxtel, M.P.; Schouten, E.G.; Kok, F.J.; Jolles, J.; Katan, M.B.; Verhoef, P. Effect of 3-Year folic acid supplementation on cognitive function in older adults in the FACIT Trial: A randomised, double blind, controlled trial. Lancet 2007, 369, 208-216. [CrossRef]

270. Balk, E.M.; Raman, G.; Tatsioni, A.; Chung, M.; Lau, J.; Rosenberg, I.H. Vitamin B6, B12, and folic acid supplementation and cognitive function: A systematic review of randomized trials. Arch. Intern. Med. 2007, 167, 21-30. [CrossRef] [PubMed]

271. Kennedy, D.O. B Vitamins and the brain: Mechanisms, dose and efficacy-A review. Nutrients 2016, 8, 68. [CrossRef]

272. Chen, H.; Liu, S.; Ji, L.; Wu, T.; Ji, Y.; Zhou, Y.; Zheng, M.; Zhang, M.; Xu, W.; Huang, G. Folic acid supplementation mitigates alzheimer's disease by reducing inflammation: A randomized controlled trial. Mediat. Inflamm. 2016, 2016, 5912146. [CrossRef]

273. Ford, T.C.; Downey, L.A.; Simpson, T.; McPhee, G.; Oliver, C.; Stough, C. The effect of a high-dose vitamin b multivitamin supplement on the relationship between brain metabolism and blood biomarkers of oxidative stress: A randomized control trial Nutrients 2018, 10, 1860. [CrossRef] 
274. Zeng, J.; Chen, L.; Wang, Z.; Chen, Q.; Fan, Z.; Jiang, H.; Wu, Y.; Ren, L.; Chen, J.; Li, T.; et al. Marginal vitamin A deficiency facilitates alzheimer's pathogenesis. Acta Neuropathol. 2017, 133, 967-982. [CrossRef] [PubMed]

275. Shahar, S.; Lee, L.K.; Rajab, N.; Lim, C.L.; Harun, N.A.; Noh, M.F.N.M.; Mian-Then, S.; Jamal, R. Association between Vitamin A, Vitamin E and apolipoprotein e status with mild cognitive impairment among elderly people in low-cost residential areas. Nutr. Neurosci. 2013, 16, 6-12. [CrossRef]

276. Yuan, C.; Fondell, E.; Ascherio, A.; Okereke, O.I.; Grodstein, F.; Hofman, A.; Willett, W.C. Long-term intake of dietary carotenoids is positively associated with late-life subjective cognitive function in a prospective study in US women. J. Nutr. 2020, 150, 1871-1879. [CrossRef] [PubMed]

277. Zeng, J.; Li, T.; Gong, M.; Jiang, W.; Yang, T.; Chen, J.; Liu, Y.; Chen, L. Marginal vitamin a deficiency exacerbates memory deficits following A?1-42 injection in rats. Curr. Alzheimer Res. 2017, 14, 562-570. [CrossRef]

278. Wołoszynowska-Fraser, M.U.; Kouchmeshky, A.; McCaffery, P. Vitamin A and retinoic acid in cognition and cognitive disease. Annu. Rev. Nutr. 2020, 40, 247-272. [CrossRef] [PubMed]

279. Soutif-Veillon, A.; Ferland, G.; Rolland, Y.; Presse, N.; Boucher, K.; Féart, C.; Annweiler, C. Increased dietary Vitamin K intake is associated with less severe subjective memory complaint among older adults. Maturitas 2016, 93, 131-136. [CrossRef] [PubMed]

280. Chouet, J.; Ferland, G.; Féart, C.; Rolland, Y.; Presse, N.; Boucher, K.; Barberger-Gateau, P.; Beauchet, O.; Annweiler, C. Dietary Vitamin K Intake is associated with cognition and behaviour among geriatric patients: The CLIP study. Nutrients 2015, 7, 6739-6750. [CrossRef]

281. Zhang, C.; Gu, Z.C.; Shen, L.; Pan, M.M.; Yan, Y.D.; Pu, J.; Liu, X.Y.; Lin, H.W. Non-Vitamin K antagonist oral anticoagulants and cognitive impairment in atrial fibrillation: Insights from the meta-analysis of over 90,000 patients of randomized controlled trials and real-world studies. Front. Aging Neurosci. 2018, 10, 258. [CrossRef]

282. Alisi, L.; Cao, R.; De Angelis, C.; Cafolla, A.; Caramia, F.; Cartocci, G.; Librando, A.; Fiorelli, M. The Relationships between vitamin K and cognition: A review of current evidence. Front. Neurol. 2019, 10, 239. [CrossRef] [PubMed]

283. Feart, C.; Helmer, C.; Merle, B.; Herrmann, F.R.; Annweiler, C.; Dartigues, J.F.; Delcourt, C.; Samieri, C. Associations of lower vitamin $\mathrm{D}$ concentrations with cognitive decline and long-term risk of dementia and alzheimer's disease in older adults. Alzheimer's Dement. 2017, 13, 1207-1216. [CrossRef]

284. Goodwill, A.M.; Szoeke, C. A systematic review and meta-analysis of the effect of low vitamin d on cognition. J. Am. Geriatr. Soc. 2017, 65, 2161-2168. [CrossRef]

285. Dursun, E.; Gezen-Ak, D. Vitamin D Basis of alzheimer's disease: From genetics to biomarkers. Hormones 2019, 18, 7-15. [CrossRef]

286. Bivona, G.; Gambino, C.M.; Iacolino, G.; Ciaccio, M. Vitamin D and the nervous system. Neurol. Res. 2019, 41, 827-835. [CrossRef] [PubMed]

287. Annweiler, C. Vitamin D in dementia prevention. Ann. N. Y. Acad. Sci. 2016, 1367, 57-63. [CrossRef]

288. Mayne, P.E.; Burne, T.H.J. Vitamin D in synaptic plasticity, cognitive function, and neuropsychiatric illness. Trends Neurosci. 2019, 42, 293-306. [CrossRef] [PubMed]

289. Morello, M.; Landel, V.; Lacassagne, E.; Baranger, K.; Annweiler, C.; Féron, F.; Millet, P. Vitamin D improves neurogenesis and cognition in a mouse model of alzheimer's disease. Mol. Neurobiol. 2018, 55, 6463-6479. [CrossRef]

290. Pearson, J.F.; Pullar, J.M.; Wilson, R.; Spittlehouse, J.K.; Vissers, M.C.M.; Skidmore, P.M.L.; Willis, J.; Cameron, V.A.; Carr, A.C. Vitamin C status correlates with markers of metabolic and cognitive health in 50-Year-Olds: Findings of the CHALICE cohort study. Nutrients 2017, 9, 831. [CrossRef]

291. Von Arnim, C.A.F.; Herbolsheimer, F.; Nikolaus, T.; Peter, R.; Biesalski, H.K.; Ludolph, A.C.; Riepe, M.; Nagel, G. Dietary antioxidants and dementia in a population-based case-control study among older people in south germany. J. Alzheimer's Dis. 2012, 31, 717-724. [CrossRef]

292. Beydoun, M.A.; Fanelli-Kuczmarski, M.T.; Kitner-Triolo, M.H.; Beydoun, H.A.; Kaufman, J.S.; Mason, M.A.; Evans, M.K.; Zonderman, A.B. Dietary antioxidant intake and its association with cognitive function in an ethnically diverse sample of US adults. Psychosom. Med. 2015, 77, 68-82. [CrossRef] [PubMed]

293. Farina, N.; Llewellyn, D.; Isaac, M.G.E.K.N.; Tabet, N. Vitamin E for alzheimer's dementia and mild cognitive impairment. Cochrane Database Syst. Rev. 2017, 2017, CD002854. [CrossRef]

294. Monacelli, F.; Acquarone, E.; Giannotti, C.; Borghi, R.; Nencioni, A. Vitamin C, aging and alzheimer's disease. Nutrients 2017, 9 , 670. [CrossRef] [PubMed]

295. Jahanshahi, M.; Nikmahzar, E.; Sayyahi, A. Vitamin E therapy prevents the accumulation of congophilic amyloid plaques and neurofibrillary tangles in the hippocampus in a rat model of alzheimer's disease. Iran. J. Basic Med. Sci. 2020, 23, 86-92. [CrossRef] [PubMed]

296. Gugliandolo, A.; Bramanti, P.; Mazzon, E. Role of vitamin E in the treatment of alzheimer's disease: Evidence from animal models. Int. J. Mol. Sci. 2017, 18, 2504. [CrossRef]

297. Reddy, V.S.; Bukke, S.; Dutt, N.; Rana, P.; Pandey, A.K. A Systematic review and meta-analysis of the circulatory, erythrocellular and CSF selenium levels in alzheimer's disease: A metal meta-analysis (AMMA Study-I). J. Trace Elem. Med. Biol. 2017, 42, 68-75. [CrossRef]

298. Varikasuvu, S.R.; Prasad, V.S.; Kothapalli, J.; Manne, M. Brain selenium in alzheimer's disease (BRAIN SEAD Study): A systematic review and meta-analysis. Biol. Trace Elem. Res. 2019, 189, 361-369. [CrossRef] [PubMed] 
299. Solovyev, N.D. Importance of selenium and selenoprotein for brain function: From antioxidant protection to neuronal signalling. J. Inorg. Biochem. 2015, 153, 1-12. [CrossRef]

300. Martínez Leo, E.E.; Segura Campos, M.R. Effect of ultra-processed diet on gut microbiota and thus its role in neurodegenerative diseases. Nutrition 2020, 71, 110609. [CrossRef] [PubMed]

301. Fieldhouse, J.L.P.; Doorduijn, A.S.; de Leeuw, F.A.; Verhaar, B.J.H.; Koene, T.; Wesselman, L.M.P.; de van der Schueren, M.; Visser, M.; van de Rest, O.; Scheltens, P.; et al. A suboptimal diet is associated with poorer cognition: The NUDAD project. Nutrients 2020, 12, 703. [CrossRef] [PubMed]

302. Chong, C.P.; Shahar, S.; Haron, H.; Che Din, N. Habitual sugar intake and cognitive impairment among multi-ethnic malaysian older adults. Clin. Interv. Aging 2019, 14, 1331-1342. [CrossRef]

303. Watt, C.; Sanchez-Rangel, E.; Hwang, J.J. Glycemic variability and CNS inflammation: Reviewing the connection. Nutrients 2020, 12, 3906. [CrossRef]

304. Sensi, S.L.; Granzotto, A.; Siotto, M.; Squitti, R. Copper and zinc dysregulation in alzheimer's disease. Trends Pharmacol. Sci. 2018, 39, 1049-1063. [CrossRef]

305. Huat, T.J.; Camats-Perna, J.; Newcombe, E.A.; Valmas, N.; Kitazawa, M.; Medeiros, R. Metal toxicity links to alzheimer's disease and neuroinflammation. J. Mol. Biol. 2019, 431, 1843-1868. [CrossRef]

306. Martins, A.C.; Morcillo, P.; Ijomone, O.M.; Venkataramani, V.; Harrison, F.E.; Lee, E.; Bowman, A.B.; Aschner, M. New insights on the role of manganese in alzheimer's disease and parkinson's disease. Int. J. Environ. Res. Public Health 2019, 16, 3546. [CrossRef]

307. Pedditzi, E.; Peters, R.; Beckett, N. The risk of overweight/obesity in mid-life and late life for the development of dementia: A systematic review and meta-analysis of longitudinal studies. Age Ageing 2016, 45, 14-21. [CrossRef]

308. Profenno, L.A.; Porsteinsson, A.P.; Faraone, S.V. Meta-analysis of alzheimer's disease risk with obesity, diabetes, and related disorders. Biol. Psychiatry 2010, 67, 505-512. [CrossRef] [PubMed]

309. Yang, Y.; Shields, G.S.; Guo, C.; Liu, Y. Executive function performance in obesity and overweight individuals: A meta-analysis and review. Neurosci. Biobehav. Rev. 2018, 84, 225-244. [CrossRef]

310. Longo, V.D.; Panda, S. Fasting, circadian rhythms, and time-restricted feeding in healthy lifespan. Cell Metab. 2016, 23, 1048-1059. [CrossRef] [PubMed]

311. Manoogian, E.N.C.; Panda, S. Circadian rhythms, time-restricted feeding, and healthy aging. Ageing Res. Rev. $2017,39,59-67$. [CrossRef] [PubMed] 